
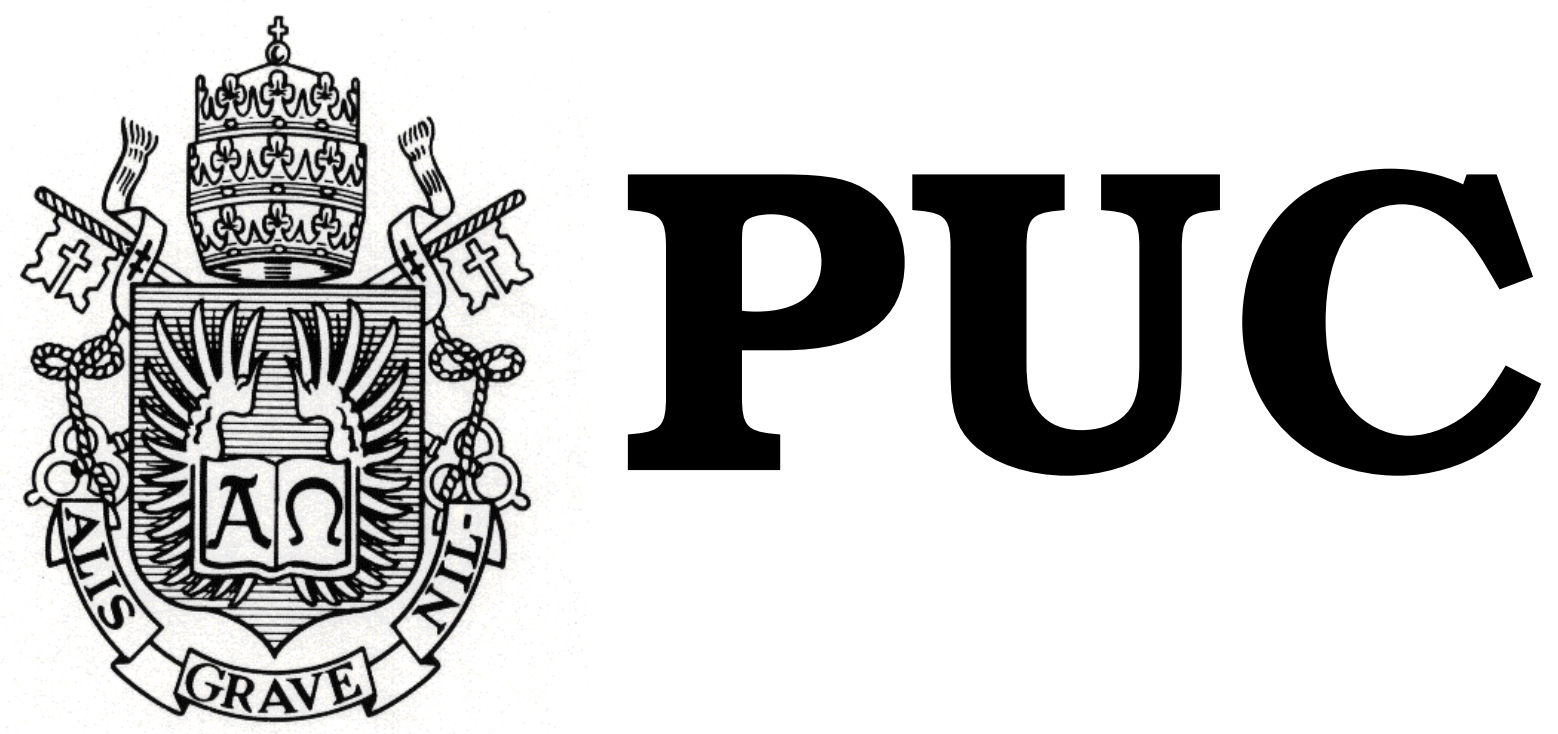

DEPARTAMENTO DE DIREITO

\title{
Panorama da Governança Corporativa no Brasil e o Novo Mercado
} por Bheatriz Pitta Corpas Moreira

Orientador: Teresa Pantoja

\section{2}

PONTIFÍCIA UNIVERSIDADE CATÓLICA DO RIO DE JANEIRO

RUA MARQUÊS DE SÃO VICENTE, 225 - CEP 22451-900

RIO DE JANEIRO - BRASIL 


\section{Panorama da Governança Corporativa no Brasil e o Novo Mercado}

\section{por}

\section{Bheatriz Pitta Corpas Moreira}

Monografia apresentada ao Departamento de Direito da Pontifícia Universidade Católica do Rio de Janeiro (PUC-Rio) para a obtenção do Título de Bacharel em Direito.

Orientador(a): Teresa Pantoja 


\section{Agradecimentos}

À minha mãe, por acreditar e investir em mim. Mãe, seu cuidado e dedicação foram fundamentais nesta caminhada. Agradeço muito a Deus por ter colocado em minha vida uma mãe tão maravilhosa

À minha avó, que me deu todo apoio e suporte para que eu tivesse tão boas oportunidades de estudo. Saudades eternas e muito obrigada, aonde quer que esteja.

Ao meu noivo, Marco, não tenho palavras para agradecer tanto apoio, paciência e dedicação. Você traz paz a minha vida. Saiba que estarei sempre ao seu lado, nos momentos bons e ruins.

À minha orientadora e professora Teresa Pantoja, por toda dedicação, paciência, cuidado e ensinamentos na orientação deste trabalho e na inspiração que traz ao ministrar suas aulas.

Ao amigo, Ricardo Maia, por toda ajuda e contribuição na busca pelos materiais que pautaram essa monografia, e que foram essenciais neste trabalho.

A todos aqueles que de alguma forma estiveram e estão próximos de mim, fazendo esta vida valer cada vez mais a pena.

Muito Obrigada, Bheatriz Pitta C. Moreira. 


\section{Resumo}

Cresceu no Brasil a constatação de que o mercado de capitais não vai progredir sem que as práticas acerca da Governança Corporativa sejam mais bem definidas nas leis, sejam aprimoradas pelas entidades reguladoras e não apenas autorreguladas, como ainda mais acentuadamente adotadas em nossas companhias.

A Governança Corporativa contribui para que a empresa adotante de suas práticas melhore seu desempenho e sua interação com seus diversos públicos, ampliando assim o acesso a recursos externos e reduzindo o custo de captação dos mesmos. A boa Governança Corporativa proporciona aos acionistas ou cotistas a gestão estratégica de sua empresa, permite uma administração melhor e mais segura, de modo que torna mais efetiva a monitoração da direção executiva. Torna assim, as empresas mais atraentes no cenário do mercado mundial.

Este trabalho busca situar a evolução da Governança Corporativa no Brasil, delineando o perfil da governança corporativa praticado pelas empresas brasileiras, bem como as principais iniciativas de estímulo às melhores práticas.

O tema, apesar da sua importância e crescente discussão, ainda precisa ser amplamente discutido e melhor assimilado na cultura do mercado de capitais brasileiro. O trabalho pretende suscitar interesse nessa linha de pesquisa e aprimorar as recomendações sobre uma melhor estrutura de governança corporativa para as empresas brasileiras, de forma que contribua para uma melhor gestão das empresas e para o desenvolvimento do mercado de capitais brasileiro. 
Nessa perspectiva, para alcançarmos o objetivo dessa monografia, buscaremos fazer uma análise dos temas que circundam a governança corporativa, seu conceito, sua finalidade e os órgãos relacionados à consecução de seu objetivo. Em seguida será observado o panorama da governança no Brasil, os problemas que as empresas brasileiras vêm enfrentando atualmente no contexto da adoção das melhores práticas de governança e uma análise da evolução dessas práticas pelas empresas nos últimos anos. Por fim, abordaremos as perspectivas para o Novo Mercado e, percorreremos os assuntos atuais que estão em discussão para que este segmento seja aperfeiçoado e mantenha suas regras atualizadas.

\section{Palavras-Chave:}

Direito Empresarial. Governança Corporativa. Panorama da Governança Corporativa no Brasil. Perspectivas para o Novo Mercado. 


\section{Sumário}

INTRODUÇÃO

Capítulo 1: O que é governança corporativa? ................................................ 13

1.1 Conflito de interesses ...................................................................... 15

1.2 Limitação técnica dos tomadores de decisão ......................................... 15

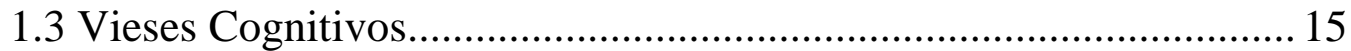

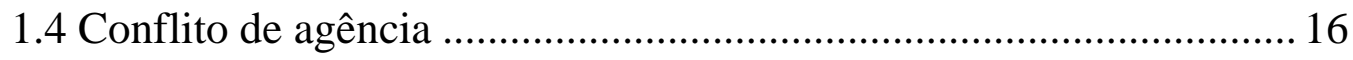

Capítulo 2: Instituto Brasileiro de Governança Corporativa (IBGC) .......... 18

2.1 Órgãos segundo o Instituto Brasileiro de Governança Corporativa .. 19

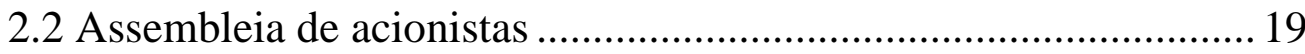

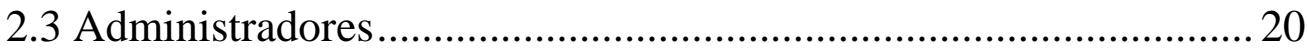

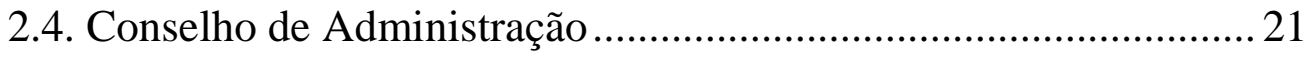

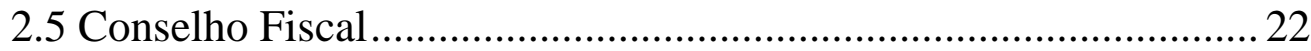

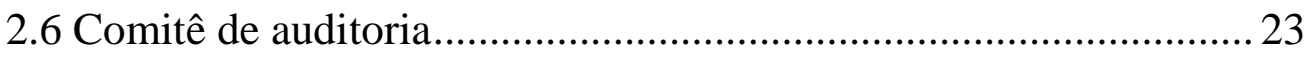

Capítulo 3: Panorama da Governança Corporativa no Brasil ...................... 25

3.1 Instrução Normativa 480 e 481 da CVM ............................................. 28

3.2 Os atuais problemas de Governança nas empresas brasileiras ........... 30

3.3 Aspectos a serem obervados no Conselho de Administração.............. 32

3.4 Maiores equívocos observados no Conselho de Administração no

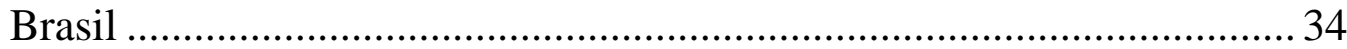

$3.5 \mathrm{O}$ preenchimento do Formulário de referência pelas companhias..... 37

3.6 Dados da evolução da Governança no Brasil........................................ 40

Capítulo 4: O Novo Mercado da Bolsa de Valores de São Paulo (BOVESPA) como um dos principais fomentos à governança corporativa

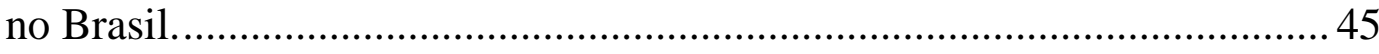

4.1 Nível 1 de Governança Corporativa..................................................... 49

4.2 Nível 2 de Governança Corporativa..................................................... 50 


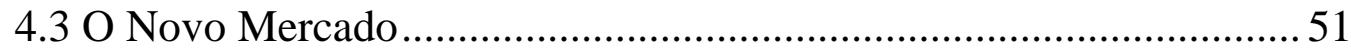

4.4 A reforma do regulamento do Novo Mercado ................................... 52

4.5 A aproximação do Nível 2 ao Novo Mercado. .....................................57

4.6 Por que grandes companhias do Ibovespa continuam fora do Novo

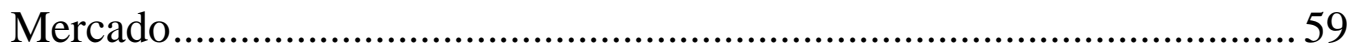

Capítulo 5: As perspectivas para o Novo Mercado .......................................... 63

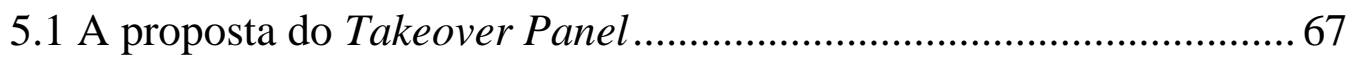

5.2 As Poison Pills e a defesa das companhias de takeover hostis.......... 69

5.3 O modelo do Comply or Explain ......................................................... 73

5.4 A divulgação da remuneração dos administradores............................. 75

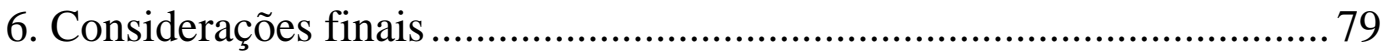

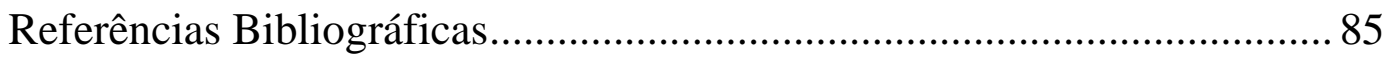




\section{Lista de abreviações}

CAF - Código de Autorregulação de aquisições e fusões

CEO - Chief Executive Officer(Diretor executivo)

CMN - Conselho Monetário nacional

CVM - Comissão de Valores Mobiliários

IBGC - Instituto Brasileiro de Governança Corporativa

IBOVESPA - Índice composto de ações emitidas por empresas que correspondem a mais de $80 \%$ do número de negócios e do volume financeiro da Bolsa.

IPO - Initial public offering (primeira oferta pública de ações)

LSA - Lei das sociedades anônimas

OPA - Oferta pública de aquisição

SEC - Securities and Exchange Comission (Comissão de Valores Mobiliários norte Americana) 


\section{INTRODUÇÃO}

Ao longo dos últimos anos o ritmo do mercado de capitais tanto brasileiro, como internacional, mostrou a relevância da adoção das melhores práticas de governança corporativa.

A busca por grandes investidores, inclusive fora dos seus países de origem, fornece às companhias oportunidades de acesso a recursos fundamentais para a otimização de sua atividade, proporcionando melhores condições para a disputa de mercados globais.

Conforme foi afirmado por Herbert Steinberg ${ }^{1}$, nada mais simples, e ao mesmo tempo, mais complicado que definir governança corporativa. Especialmente, se levadas em consideração às realidades política, cultural, social, empresarial e jurídica brasileiras, que tornam a tarefa ainda mais árdua, tornando extremamente apropriada a associação da expressão "dimensão humana" à governança, como feito por aquele autor ${ }^{2}$.

De todo modo, a governança corporativa pode ser definida como o esforço contínuo em alinhar os objetivos da administração das empresas aos interesses dos acionistas. Isso envolve as práticas e os relacionamentos entre os acionistas/cotistas, o conselho de administração, a diretoria, uma auditoria independente e até mesmo um conselho fiscal. ${ }^{3}$

Pode ela também ser definida como o sistema pelo qual as companhias são dirigidas e controladas, ${ }^{4}$ de modo a descobrir meios de assegurar a eficácia das decisões.

Deste modo, trata-se da utilização de práticas e condutas aplicáveis na consecução das atividades empresariais, por meio de métodos que tornem mais proba e transparente a atuação daqueles que têm o poder

\footnotetext{
${ }^{1}$ STEINBERG, Hebert. Apud Guilherme N. Dale, in A dimensão humana da governança corporativa, pessoas criam as melhores e as piores práticas. Editora Gente. 2003.

${ }^{2}$ CLEMENTE, Eduardo Silveira. Governança Corporativa e questões jurídicas concretas. Disponível em: <http://jus.com.br/revista/texto/6049/governanca-corporativa-e-questoes-juridicasconcretas/1>. Acessado em 05.10.2012.

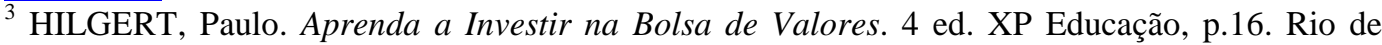
Janeiro, jan 2011.

${ }^{4}$ CADBURY, Adrian. The Cadbury Report - Relatório do Committee on the Financial Aspects of Corporate Governance, 1992.
} 
administrativo, instrumentalizando a vida societária de modo a propiciar efetividade aos diversos interesses envolvidos na companhia. ${ }^{5}$

A boa governança corporativa permite uma administração ainda melhor e o monitoramento da direção executiva da empresa. ${ }^{6}$ A companhia que opta pelas boas práticas de governança corporativa adota como pressupostos imprescindíveis à transparência, a prestação de contas e a equidade.

Frente à realidade legislativa brasileira, que não propicia instrumentos suficientemente eficazes em harmonizar os diversos interesses confluentes na companhia aberta, e, portanto, vem sendo incapaz de estimular o desenvolvimento do mercado de capitais brasileiro, houve a recepção da governança corporativa, como instrumento contratual de balizamento de gestão das companhias. ${ }^{7}$

No Brasil, as grandes conquistas do desenvolvimento da governança corporativa foram a atração do fluxo capital estrangeiro e a criação de uma cultura mais disseminada das práticas de negociação de ações no país. ${ }^{8}$

Com a progressiva mudança da economia brasileira, sobretudo na estrutura de propriedade e gestão de suas principais empresas, as relações entre acionistas e administradores estão sendo cada vez mais questionadas com a reestruturação societária e a entrada de novos sócios no setor privado, principalmente de investidores estrangeiros.

Esses fatores trazem duas consequências incongruentes: da mesma forma pela qual tornam o capital mais acessível e impulsionam a melhora da gestão nas empresas, acabam por gerar a colisão dos interesses entre os acionistas e os administradores.

\footnotetext{
${ }^{5}$ FARIA, Andréa. Primeiras anotações sobre governança corporativa. Piracicaba, SP. 2010.56 p. Dissertação (Mestrado). Departamento de direito da Universidade Metodista de Piracicaba.

${ }^{6}$ HILGERT, Paulo. Aprenda a Investir na Bolsa de Valores. 4 ed. XP Educação. p.16. Rio de Janeiro, jan. 2011.

${ }^{7}$ FARIA, Andréa. Primeiras anotações sobre governança corporativa. Piracicaba, 2010. 54 p. Dissertação (Mestrado). Departamento de direito da Universidade Metodista de Piracicaba.

${ }^{8}$ PRADO, José Domingos. Uma década de Novo Mercado. Revista Capital Aberto Especial, São Paulo, p.51, 02 abril 2012.
} 
Torna-se assim necessário um realinhamento dos interesses das duas partes. Este complexo rol de questões que envolvem a relação entre propriedade e gestão pode encontrar seu tratamento no âmbito do conceito de governança corporativa.

O mecanismo de governança corporativa é formado por um complexo de regulamentos, convenções culturais e instituições que disciplinam a relação dos administradores das companhias, os acionistas e outros grupos cuja administração deve prestar contas. ${ }^{9}$

Com a economia cada vez mais integrada, é imprescindível que as empresas brasileiras tenham um novo posicionamento, visto que o custo para a captação de recursos para o financiamento de projetos é alto, o sistema tributário ineficiente, e isso, em conjunto com o alto custo de uma companhia aberta e os altos juros praticados no mercado brasileiro, todos contribuem para dificultar o financiamento das companhias brasileiras.

Para solucionar essas questões, o mercado de capitais aparece como importante solução e por isso, vem se aprimorando cada vez mais nos últimos anos. As empresas visam cada vez mais à credibilidade social e o baixo custo do capital, para tanto, é necessário que inovações no que se refere à governança corporativa sejam cada vez mais discutidas e avaliadas.

O maior exemplo desse aperfeiçoamento do mercado de capitais é sem dúvida o Novo Mercado, que acabou de completar dez anos.

Criado pela Bovespa em 2001, o Novo Mercado é um segmento de listagem, uma classificação composta por empresas que se comprometem, voluntariamente, a praticar uma boa governança corporativa e uma política de disclosure (transparência de informações estratégicas e financeiras), para além do que é exigido pela legislação. Com o Novo Mercado, a bolsa busca atrair novos investidores, exigindo que as companhias tratem os acionistas

\footnotetext{
${ }^{9}$ LETHBRIDGE, E. Tendências da Empresa Familiar no Mundo. Revista BNDES no 6. Rio de Janeiro, p. 2. 1997.
} 
com mais respeito, resguardando os seus direitos e oferecendo uma gama maior de informações, cuja divulgação não é obrigatória por $1 \mathrm{ei}^{10}$.

O aprimoramento dos níveis de governança corporativa depende de uma mudança de atitude dos agentes do mercado, por meio de ferramentas de auto regulação, determinados por entidades associativas dos vários segmentos.

A celebração de uma década da concepção e implantação, pela Bovespa, dos segmentos especiais de negociação de ações, especialmente o Novo Mercado, reforça, na prática, a evolução permanente do mercado de capitais no Brasil.

A instituição do Novo Mercado expõe importante fonte de respostas, baseadas em critérios de governança muito bem balizados, as demandas de investidores brasileiros e estrangeiros atentos ao bom desempenho da economia brasileira ${ }^{11}$.

Hoje o Novo Mercado é um segmento reconhecido internacionalmente, e um modelo que outros países tentam reproduzir.

Às empresas veteranas da Bolsa, o Novo Mercado ofereceu uma oportunidade de se reestruturarem, superarem crises e melhorarem a relação com os investidores em condições muito mais amistosas. Às empresas novas e desconhecidas dos investidores, possibilitou uma boa estrutura para abertura de capital. Aos reguladores, foi uma forma de elevar as obrigações de transparência e governança sem mexer na lei ou na regulamentação ${ }^{12}$.

Ao longo desses dez anos, é indubitável concluir ter sido enorme a contribuiçãa que a ampliação das práticas de governança corporativa, entre elas a instituição do Novo Mercado trouxeram para a evolução do mercado acionário brasileiro, e por consequência, para o desenvolvimento da economia.

\footnotetext{
${ }^{10}$ HILGERT, Paulo. Aprenda a Investir na Bolsa de Valores. 4 ed. XP Educação. p.17. Rio de Janeiro, jan. 2011.

${ }^{11}$ PRADO, José Domingos. Uma década de Novo Mercado. Revista Capital Aberto Especial, n. 33, São Paulo, p. 51, abril 2012.

${ }_{12}$ AZEVEDO, Simone. Um orgulho para o Brasil. Revista Capital Aberto Especial, n.33, São Paulo, p. 4, abril 2012.
} 
A instituição de níveis sofisticados de negociação, juntamente com a significativa melhoria da economia brasileira, levou a uma enorme expansão do mercado acionário no Brasil: novas companhias abertas surgiram, vultosos recursos foram captados no mercado acionário, e um importante aumento no volume de negociações de ações foi registrado ${ }^{13}$.

O êxito do Novo Mercado se deve a precisa previsão dos problemas que abatiam o mercado, da perseverança em empenhar-se numa solução nunca antes contemplada, da insistência em conservar o propósito mesmo diante das dificuldades, e pelo bom momento da economia brasileira.

Agora, o Novo Mercado enfrenta o obstáculo de manter suas regras atualizadas. Para que o segmento continue tendo sucesso é indispensável que haja um aperfeiçoamento contínuo de suas regras, de forma que continue evoluindo e atendendo às expectativas dos investidores.

${ }^{13}$ CANTIDIANO, Leonardo. Novo Mercado: Dez anos de sucesso. Revista Capital Aberto. Disponível em : < http://www.capitalaberto.com.br/ler artigo.php?pag=3\&sec=99\&i=4684> Acessado em 05.10.2012. 


\section{Capítulo 1: O que é governança corporativa?}

Governança Corporativa é um constructo ${ }^{14}$, é um tema complexo e de natureza multidisciplinar, composto por variáveis de diversos campos de conhecimento, como economia, finanças, contabilidade, teoria organizacional, direito, sociologia, ética, comunicação e teoria da informação ${ }^{15}$.

Há diversas definições na literatura para "Governança Corporativa", que variam de acordo com a visão e experiência do autor.

A governança corporativa está relacionada à distribuição de poder na empresa, suas práticas de gestão e fiscalização. É um tema que lida com diferentes partes interessadas, tais como acionistas, diretoria executiva, conselho de administração, conselho fiscal, auditorias independentes, empregados, fornecedores, órgãos normativos do mercado de capitais, comunidade e em sentido amplo o próprio interesse público. Trata-se de mecanismos que tem como objetivo fazer com que as decisões das organizações empresariais sejam tomadas de forma a maximizar a perspectiva de geração de valor de longo prazo para o negócio. ${ }^{16}$

A Comissão de Valores Mobiliários $(\mathrm{CVM})^{17}$, define Governança Corporativa como:

"O conjunto de práticas que tem por finalidade otimizar o desempenho de uma companhia ao proteger todas as partes interessadas, tais como investidores, empregados e credores, facilitando o acesso ao capital. A análise das práticas de governança corporativa aplicada ao mercado de capitais envolve, principalmente: transparência, equidade de tratamento dos acionistas e prestação de contas."

$\mathrm{Ou}$, analisando o conceito na perspectiva do Instituto Brasileiro de Governança Corporativa (IBGC) ${ }^{18}$ :

\footnotetext{
${ }^{14}$ Categoria que somente pode ser compreendida a partir do estudo de um conjunto de conceitos.

${ }^{15}$ BRANDÃO, Mônica. Governança corporativa e a influência dos acionistas minoritários no sistema de decisões estratégicas. Disponível em: <http://mrm.comuniquese.com.br/arq/132/arq_132 13827.pdf >. Acesso em 05.10.2012.

${ }^{16}$ MICELI, Alexandre. Governança Corporativa. Sustentare Escola de Negócios, Curso de Pós Graduação Lato sensu. Abril 2011. Disponível em:< http://www.slideshare.net/Sustentare/governana-corporativa-prof-dr-alexandre-di-miceli-dasilveira-sustentare-8415874 >. Acesso em 05.10.2012.

${ }^{17}$ CVM, publicação. Uma década de Governança Corporativa, 2006, p. 63.
} 
"Governança Corporativa é o sistema pelo qual as organizações são dirigidas, monitoradas e incentivadas, envolvendo os relacionamentos entre proprietários, conselho de administração, diretoria e órgãos de controle. As boas práticas de governança corporativa convertem princípios em recomendações objetivas, alinhando interesses com a finalidade de preservar e otimizar o valor da organização, facilitando seu acesso ao capital e contribuindo para a sua longevidade."

\section{Para Milton Nassau Ribeiro:}

"A governança corporativa é um sistema de gestão que privilegia o uso de instrumentos (lei, regulamentos e práticas comerciais), visando compatibilizar os diversos interesses daqueles que se relacionam com a companhia, ou seja, controladores, administradores, minoritários, comunidade e stakeholders. "19

A governança corporativa produz um impacto no valor das companhias, na medida em que empresas com boa governança são mais procuradas pelos investidores, o que leva a uma redução no custo de seu capital bem como aumento do valor de seus papéis. ${ }^{20}$

Não obstante, há também os benefícios internos para a companhia, como o aprimoramento do processo decisório dos principais executivos, conselheiros, presidente, com uma definição mais clara da competência de cada personagem, separação mais clara dos papéis entre acionistas, conselheiros e executivos, menor dependência de pessoas específicas e maior transparência perante os stakeholders ${ }^{21}$, tudo isso leva a diminuição da probabilidade de fraude, tendo em vista que há um melhor gerenciamento dos riscos e um controle interno mais eficiente.

Tendo em vista que existem três potenciais dificuldades que envolvem as decisões das companhias, quais sejam: o conflito de interesses, limitações técnicas individuais e vieses cognitivos, torna-se necessária a presença de uma eficiente governança corporativa.

\footnotetext{
${ }^{18}$ Disponível em: < HTTP:// www.ibgc.org.br >. Acesso em 12.09.2012.

${ }_{19}^{19}$ RIBEIRO, Milton Nassau. Aspectos Jurídicos da Governança Corporativa. Belo Horizonte: Del Rey, 2007. 384 p.

${ }^{20}$ MICELI, Alexandre. Governança Corporativa. Sustentare Escola de Negócios, Curso de Pós Graduação Lato sensu. Abril 2011. Disponível em:< http://www.slideshare.net/Sustentare/governana-corporativa-prof-dr-alexandre-di-miceli-dasilveira-sustentare-8415874> Acessado em 05.10.2012.

${ }^{21}$ Representa todos os grupos ou indivíduos que têm interesse, exercem influência ou contribuem para o sucesso dos negócios de uma empresa, e que impactam na gestão de uma companhia, tais como empregados, clientes, credores, órgãos governamentais, fornecedores e etc.
} 


\subsection{Conflito de interesses}

Segundo Alexandre di Miceli²2, o conflito de interesses se evidencia no fato de que indivíduos com poder decisório podem preferir tomar suas decisões de forma a maximizarem seu bem-estar pessoal ou o bem-estar de quem o elegeu, em detrimento do melhor resultado para a companhia.

Executivos, grupos de controle ou acionistas de empresas de alta concentração acionária muitas vezes tomam decisões com a intenção focada em suas carreiras, em aumentar seu resultado individual, em detrimento do valor da companhia e dos demais acionistas.

\subsection{Limitação técnica dos tomadores de decisão}

O autor observa o fato de que decisões tomadas por uma só pessoa não são as decisões mais eficazes, visto que uma pessoa sozinha não costuma possuir todos os conhecimentos técnicos necessários de áreas diferentes para tomar decisões fundamentais em uma companhia tais como as relacionas a marketing, investimento, posicionamento estratégico, financiamento e etc., torna-se imprescindível um Conselho de Administração qualificado, que reúna pessoas com diferentes formações, visões e experiências para que os executivos possam tomar decisões melhores e mais abrangentes.

\subsection{Vieses Cognitivos}

Conforme as lições de Alexandre di Miceli, há uma extensa pesquisa em psicologia que demonstra que em situações de conflitos de interesses, mesmo que todas as partes ajam com absoluta ética e sejam extremamente qualificadas, há de haver um sistema decisório balanceado,

\footnotetext{
${ }^{22}$ MICELI, Alexandre. Governança Corporativa. Sustentare Escola de Negócios, Curso de Pós Graduação Lato $\quad$ sensu. $\quad$ Abril $2011 . \quad$ Disponível em:<http://www.slideshare.net/Sustentare/governana-corporativa-prof-dr-alexandre-di-miceli-dasilveira-sustentare-8415874>. Acesso em 05.10.2012.
} 
de "pesos e contrapesos", para que possa haver uma boa governança corporativa.

$\mathrm{O}$ autor segue com o exemplo ${ }^{23}$, de que um empreendedor atuando como $C E O^{24}$ pode ser excessivamente otimista em relação às perspectivas do negócio, ou então, um conselho excessivamente homogêneo pode reforçar opiniões mútuas, evitando questionamentos.

\subsection{Conflito de agência}

As dificuldades e conflitos entre executivos e proprietários são problemas existentes há muitas décadas, visto que a preocupação ou o ponto de vista dos executivos costuma ser diferente dos proprietários.

Adam Smith já havia citado no século XVIII em "A riqueza das nações" as questões fundamentais que ocasionam os problemas de governança, sendo que na verdade a origem dos problemas de governança existe bem antes dos textos de Smith, visto que se trata de um problema relacionado à natureza humana, pois o indivíduo tende a procurar maximizar seu bem estar pessoal ao longo de sua vida.

No entanto, segundo Di Micelli ${ }^{25}$, esse comportamento aplicado à realidade de uma companhia, pode levar um indivíduo a tomar decisões prejudiciais a terceiros, mormente aos investidores que confiaram a esta pessoa o poder para a tomada de decisões em seu nome e interesse. Assim, há um problema de "governo" nestas companhias e organizações.

Para discutir esse tema a teoria mais aceita é a teoria do agenteprincipal, no qual os executivos tomam decisões com o intuito de

\footnotetext{
${ }^{23}$ MICELLI, Alexandre. Governança Corporativa. Sustentare Escola de Negócios, Curso de Pós Graduação Lato sensu. Abril 2011. Disponível em:< http://www.slideshare.net/Sustentare/governana-corporativa-prof-dr-alexandre-di-miceli-dasilveira-sustentare-8415874 >. Acesso em 05.10.2012.

${ }^{24}$ CEO (Chief Executive Officer) é o cargo que está no topo da hierarquia operacional de uma empresa. Ele possui a responsabilidade de executar as diretrizes propostas pelo Conselho de Administração, que por sua vez é composto por representantes dos acionistas da empresa. Apesar de ser possível haver mais de um $C E O$ numa empresa, normalmente o posto é ocupado por somente um indivíduo, temendo-se que tal compromisso crie conflito dentro da organização sobre quem tem o poder de decisão. Todos os outros executivos prestam contas ao CEO. Disponível em: $<$ http://pt.wikipedia.org/wiki/Diretor_executivo> Acesso em 05.10.2012.

${ }^{25}$ MICELI, Alexandre. Governança Corporativa. Op.cit.
} 
maximizar sua utilidade pessoal, em detrimento da riqueza dos acionistas, fugindo do motivo pelo qual foram contratados.

Conforme Adam Smith, em sua obra The Wealth of Nations ,"sendo os executivos de companhias abertas gestores do dinheiro de outras pessoas, não se pode esperar que eles vigiem o negócio com a mesma intensidade que os donos de empresas fechadas" (tradução adaptada).

Assim, na teoria econômica tradicional a governança corporativa serve para superar esse conflito de agência.

Para tanto, a teoria da agência visa lidar com os inconvenientes que surgiram com a separação entre propriedade e gestão, chamados de problemas de agência, e tem representado a perspectiva teórica aplicada aos estudos de governança corporativa.

Segundo Alexandre di Miceli $^{26}$, a maior parte da literatura sobre governança corporativa foi desenvolvida para o contexto anglo-saxão, no qual o principal conflito de agência ocorre entre acionistas e gestores, em decorrência da estrutura de propriedade pulverizada da maior parte das companhias abertas. No entanto, na maior parte do mundo, inclusive no Brasil, há outro cenário no qual predomina a concentração da estrutura de propriedade por um grande acionista, ou um bloco grande de acionistas, sendo assim, o conflito de agência ocorre entre os acionistas controladores e os minoritários.

\footnotetext{
${ }^{26}$ MICELI, Alexandre. Governança Corporativa. Sustentare Escola de Negócios, Curso de Pós Graduação Lato sensu. Abril 2011. Disponível em:< http://www.slideshare.net/Sustentare/governana-corporativa-prof-dr-alexandre-di-miceli-da-

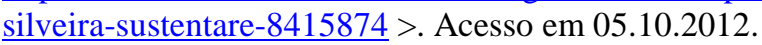




\section{Capítulo 2: Instituto Brasileiro de Governança Corporativa (IBGC)}

O Instituto Brasileiro de Governança Corporativa (IBGC) teve início em 1994 quando o administrador de empresas Bengt Hallqvist e o consultor João Bosco Lodi perceberam que era necessário haver um órgão com o intuito de colaborar com a qualidade da alta gestão das organizações brasileiras. ${ }^{27}$

Juntamente com um grupo de 36 (trinta e seis) pessoas, entre empresários, conselheiros, consultores e estudiosos, fundaram em 1995, o Instituto Brasileiro de Conselheiros de Administração (IBCA), com o objetivo de fortalecer a atuação desse órgão, supervisionando e controlando as empresas. Entretanto, as preocupações foram aos poucos sendo ampliadas para questões ligadas a relação entre, propriedade, diretoria, conselho fiscal e auditoria independente.

Em 1999, o instituto mudou sua denominação para Instituto Brasileiro de Governança Corporativa (IBGC), tendo obtido o reconhecimento internacional, sendo considerado no Brasil e no exterior como a principal referência na difusão de melhores práticas de Governança na América Latina.

Juntamente com a Bovespa, em 1999, dado um consenso da necessidade de serem elencadas as atitudes e os comportamentos que as empresas de forma voluntária deveriam observar com o objetivo de estreitar as relações de confiança entre os acionistas, os administradores e as partes interessadas, lançou o Código de Melhores Práticas de Governança Corporativa.

O Código sugere as melhores indicações para que todos os tipos de empresas aprimorem seu desempenho e obtenham um acesso mais fácil ao capital.

\footnotetext{
${ }^{27}$ IBGC. Disponível em: < http://www.ibgc.org.br/Historico.aspx > Acesso em 06.10.2012.
} 


\section{1 Órgãos segundo o Instituto Brasileiro de Governança Corporativa}

\subsection{Assembleia de acionistas}

A Assembleia Geral (artigos 121 e seguintes da lei 6.404/76) é considerada órgão soberano da organização de capital aberto, e deve constituir foro adequado para reflexões, discussões e solução de questões atinentes a companhia, cabendo-lhe a deliberação de todos os assuntos da companhia. Assim, antes de serem iniciadas as deliberações deve haver análise, preparação e articulação de forma que haja uma contribuição positiva na Assembleia.

Para tanto, o IBGC sugere que as companhias considerem aspectos de ordem logística para a realização da assembleia, bem como sugere que quando houver complexidade das questões, as companhias efetuem a primeira convocação para Assembleia Geral com antecedência mínima de 30 (trinta) dias corridos, ao invés de 15 (quinze) dias corridos. E, quando se tratar de operações que possam importar alterações fundamentais na companhia e nos investimentos dos acionistas que sejam adotados prazos mais dilatados que 30 (trinta) dias corridos.

Ademais, o IBGC recomenda que os Editais de Convocação sejam claros, precisos e bem definidos, de forma a atender a manifestação da CVM no sentido da vedação de matérias que dependam de deliberação assemblear sob a rubrica de "assuntos gerais" no corpo do edital de convocação.

Desta forma, deve a companhia estar consoante o cumprimento estrito das disposições previstas na legislação e no estatuto social sobre a convocação e fornecimento de informações tempestivas e suficientes aos acionistas. 


\subsection{Administradores}

As sociedades atuam por meio de seus órgãos societários, dentre eles a diretoria; este fato é denominado de caráter orgânico da sociedade.

Conforme determina a Lei das Sociedades Anônimas (art. 138) a administração da companhia compete ao Conselho e à Diretoria, ou somente à última, nas situações em que o Conselho não é obrigatório ou ainda não tenha sido constituído.

Os conselheiros são eleitos pela Assembleia Geral (art. 140 da Lei 6.404/76), e estes elegem os diretores (art. 142, inciso II da Lei 6.404/76). Desta forma, os administradores são os conselheiros e diretores eleitos na forma do Estatuto Social.

A diretoria (art. 143 da LSA) é órgão obrigatório da companhia, composto por 02 (dois) ou mais diretores, eleitos e destituídos a qualquer tempo pelo conselho de administração, ou, se inexistente, pela assembleia geral. Dentre suas atribuições estão à administração direta da sociedade, cabendo-lhe realizar em concreto os objetivos sociais e metas traçadas pela assembleia geral e o conselho de administração.

De acordo com o Guia de Orientação Jurídica de Conselheiros de Administração e Diretores disponibilizado pelo $\mathrm{IBGC}^{28}$, os administradore ${ }^{29}$ corporificam a companhia, sendo por intermédio dele que a sociedade expressa a sua vontade, são eles responsáveis pela gestão e representação ativa e passiva da companhia, assim, eles tem o poder de assinar contratos, cheques e outros documentos em nome da companhia, sendo seu poder emanado da própria lei das Sociedades Anônimas, não dependendo de procuração.

\footnotetext{
${ }^{28}$ Guia de Orientação Jurídica de Conselheiros de Administração e Diretores. Disponível em: $\langle$ http://www.ibgc.org.br/PressRelease.aspx?CodPressRelease=433 $\rangle$. Acessado em 06.10.2012. ${ }_{29}$ Neste sentido, lei 6.404/76: "Art. 146. Poderão ser eleitas para membros dos órgãos de administração pessoas naturais, devendo os diretores ser residentes no País."
} 


\subsection{Conselho de Administração}

Segundo o modelo de regimento interno fornecido pelo $\mathrm{IBGC}^{30}$, o Conselho de Administração tem como objetivo proteger, valorizar e maximizar o patrimônio da companhia e o retorno do investimento. Para isso, deve estar em consonância com os valores da empresa, e propósito dos acionistas, sempre buscando o aprimoramento.

A governança é de fato exercida pelo conselho de administração e pela diretoria executiva, nos quais os acionistas, os stakeholders, o controle corporativo de mercado e as regulações nacionais e internacionais interagem para afetar as ações da empresa e o monitoramento dos gerentes $^{31}$. Pode-se dizer que funciona como um filtro entre os interesses dos acionistas (outorgantes) e dos gestores (outorgados) ao recordar a estes o que aqueles querem e ao minimizar a ingerência do acionista do negócio ${ }^{32}$.

O Conselho de Administração (artigos 138 e seguintes, da Lei 6.404/76), é um órgão de deliberação colegiada, sendo obrigatório para as companhias de capital aberto ou autorizado, e facultativo para as companhias fechadas. (art. 138, parágrafo segundo da Lei 6.404/76).

Deve ser composto por no mínimo 3 (três) membros, eleitos pela assembleia geral e por ela destituíveis a qualquer tempo (art. 140 da Lei 6.404/76). No artigo 142 da LSA, estão elencadas as competências do Conselho de Administração, dentre as quais podemos citar: à constituição de comitês, que deverão ter atribuições específicas sobre determinadas matérias; a aprovação de regimentos internos; a nomeação do Comitê de Auditoria, a aprovação da política de gestão de risco; a convocação da Assembleia Geral, bem como a aprovação do plano estratégico, os

\footnotetext{
30 Modelo de regimento interno de Conselho de Administração. Disponível em: < http://www.bmfbovespa.com.br/pdf/ModeloRegimentoInternoCA.pdf > . Acessado em 06.10.2012. 31 ANDRADE, Adriana; ROSSETTI, José Paschoal. Governança Corporativa: Fundamentos, desenvolvimento e tendências. 2a ed. São Paulo: Atlas, 2006, p. 239.

${ }^{32}$ STEINBERG, Herbert. A dimensão humana da Governança Corporativa: pessoas criam as melhores e piores práticas. São Paulo. Editora Gente, 2003, p. 84.
} 
respectivos planos plurianuais, e programas anuais de dispêndio e investimento.

Para tanto, deve orientar de forma generalizada os negócios da companhia, além de estar à frente das decisões em questões estratégicas objetivando zelar pelos interesses dos acionistas, sem preterir as demais partes interessadas (stakeholders), deve prevenir e administrar situações de conflito de interesses, zelando pela perenidade da companhia, atuando com profissionais qualificados e de reputação ilibada, para que haja uma gestão ágil, que garanta que as estratégias e diretrizes sejam efetivamente implementadas pela diretoria, de forma a não interferir nos assuntos operacionais.

Além disso, deve o Conselho de Administração realizar seu objetivo dentro de uma perspectiva de longo prazo, sempre observando o objeto social da companhia e suas controladas, e de preferência, ao definir seus negócios, deve tomar decisões que visem à sustentabilidade, que incorpore considerações de ordem econômica, social, ambiental e de boa governança corporativa.

\subsection{Conselho Fiscal}

De acordo com o artigo 109, inciso III, da Lei $6.404 / 76^{33}$, o acionista tem o direito de fiscalizar a gestão dos negócios sociais e para isso vale-se do Conselho Fiscal (art. 161 e seguintes da LSA), que atua elaborando pareceres, recomendações, dando opiniões, recebendo denúncias, além da fiscalização das contas e dos atos dos administradores.

De acordo com o Guia de Orientação do Conselho Fiscal, fornecido pelo $\mathrm{IBCG}^{34}$, para que o conselho fiscal seja eficaz deve ser independente frente à administração da companhia, bem como frente aos acionistas e a

\footnotetext{
${ }^{33}$ Lei 6.404, Art. 109 "Nem o estatuto social nem a assembléia-geral poderão privar o acionista dos direitos de:III - fiscalizar, na forma prevista nesta Lei, a gestão dos negócios sociais;"

34 Guia de orientação para o Conselho Fiscal. Disponível em: < http://www.ibgc.org.br/CadernoGovernanca.aspx?CodCaderno=2> . Acesso em 06.10.2012.
} 
diretoria; devem os conselheiros ter atuação crítica e construtiva nos campos financeiro, legal e de negócios, sendo pró ativos na busca de informações relevantes para formarem seu juízo; além de que a companhia deve ser transparente para com informações necessárias ao pleno desempenho da função de conselheiro.

Segundo sugestão do IBGC, devem os conselheiros, dentre outras atividades, acompanhar a execução dos orçamentos de operação e manutenção e de investimentos, acompanhar a pontualidade da empresa no cumprimento de suas obrigações, acompanhar e fiscalizar a política de distribuição de dividendos, divulgação de informações, acompanhar os volumes e valores dos títulos de emissão da companhia negociados na bolsa, solicitando informações sempre que verificar movimentos anormais, além de articular-se com as demais instâncias internas a fim de rever plano de trabalho e examinar a adequação das atividades, desta forma, buscar através dos princípios da transparência, equidade de prestação de contas contribuir para o melhor desempenho da companhia.

\subsection{Comitê de auditoria}

O Conselho de administração pode ter diversos comitês, com especificidades diversas, e um desses comitês é o de auditoria. Assim, deve agir em nome do Conselho de Administração, operacionalizando os deveres e responsabilidades da gestão de processos internos, assegurando a efetividade dos controles internos e a produção dos relatórios financeiros, a fim de proteger o interesse dos acionistas e de outras partes.

Desta forma, visa assegurar ao Conselho de Administração a qualidade da controladoria interna e dos demonstrativos financeiros, além de atuar na gestão de risco da companhia; assim, prepara demonstrações e informações financeiras para os investidores e o mercado. 
De acordo com o Guia de Orientação para Melhoras Práticas de Comitês de Auditoria fornecido pelo $\mathrm{IBGC}^{35}$, deve-se frisar que o Conselho Fiscal e o Comitê de Auditoria possuem funções distintas. Enquanto o primeiro é um órgão independente da diretoria e do Conselho de Administração. O Comitê de Auditoria é um órgão ligado ao conselho de administração e seus membros são preferencialmente provenientes deste órgão, segundo o IBGC o Comitê de Auditoria é o órgão que melhor atende à função de controle de relacionamento do Conselho de Administração com a auditoria interna e externa.

O IBGC recomenda que os conselheiros do Comitê de Auditoria sejam constituídos preferencialmente por conselheiros independentes, pelo menos em sua maioria. Esta independência está relacionada com a capacidade de exercer julgamentos e demonstra-se na forma como desempenha-se a função.

${ }^{35}$ Guia de orientação para melhores práticas de comitês de auditoria. Disponível em: < http://www.ibgc.org.br/CadernoGovernanca.aspx?CodCaderno=53>. Acessado em 06.10.2012. 


\section{Capítulo 3: Panorama da Governança Corporativa no Brasil}

Segundo a superintendente-geral do Instituto Brasileiro de Governança Corporativa, Heloísa B. Bedicks ${ }^{36}$, ao fazer uma retrospectiva verificamos importantes marcos na evolução dos mercados de capitais e das organizações nacionais e internacionais. Crises nos sistemas e nas dinâmicas corporativas e financeiras foram seguidas por melhorias nos processos regulatórios e autorregulatórios dos mercados, que ocorreram tanto devido à criação dos códigos de melhores práticas de governança corporativa e aperfeiçoamento legal, como por iniciativas voluntárias.

No final dos anos 1980, na Inglaterra, em iniciativa a insatisfação dos acionistas em relação à forma como as empresas nas quais eles investiam estavam sendo geridas pelos seus administradores, houve a publicação de um código que detalhou as boas práticas de sistemas e balanceamentos para as empresas, o Relatório Cadbury, que veio a influenciar futuras publicações.

No Brasil, o movimento por boas práticas mostrou-se mais dinâmico a partir dos processos de sua inserção global, das privatizações e da desregulamentação do mercado nacional. Em paralelo, em 1995, ocorreu à criação do atual Instituto de Governança Corporativa (IBGC), com o objetivo de influenciar as companhias a adotarem práticas transparentes, responsáveis e equânimes.

Desta forma, em 2000, a bolsa de valores de São Paulo criou, influenciado pelo modelo alemão Neuer Market, o Novo Mercado, no qual as regras centram-se em patamares superiores de governança corporativa.

De ingresso voluntário, o Novo Mercado levou algumas empresas brasileiras a adotarem melhores práticas, sendo um marco na evolução do mercado de capitais brasileiro. A reforma da Lei das Sociedades Anônimas,

\footnotetext{
${ }^{36}$ BEDICKS, Heloísa. Os motivos de governança: uma questão de saúde. Disponível em: < http://www.diagnosticoweb.com.br/especiais/os-motivos-da-governanca-uma-questao-desaude.html >. Acessado em 07.07.2010.
} 
a publicação do Código do IBGC e o interesse crescente dos fundos de pensão também foram fatores que impulsionaram o mercado.

Neste ínterim, conforme Heloísa Bedicks ${ }^{37}$, devido aos escândalos corporativos e relacionados a fraudes contábeis que ocorrem nos Estados Unidos, foi aprovada, a Lei Sarbanes-Oxley $(S O x)^{38}$, que aprofundou as questões de gestão de riscos e estabelecimento formal de responsabilidade pelos administradores. Em seguida, importantes empresas na Europa apresentaram problemas de governança, motivo pelo qual foi adotado em alguns países regras mais rígidas no que tange a divulgação de informações, nomeadas de "comply or explain", em que a empresa deve indicar se adota práticas de governança e explicar o motivo quando não está em conformidade com elas.

Acompanhando a evolução das práticas envolvendo a boa governança, a evolução normativa no Brasil veio em passos lentos na contrapartida das tendências econômicas internacionais, internalizando conceitos e aplicações práticas no cotidiano das empresas. ${ }^{39}$

De forma tímida, prossegue a autora, começou-se a importar a experiência, os modelos e as regras já adotadas internacionalmente.

As empresas de capital aberto, na busca por novos mercados, passaram a participar do cenário externo para a captação de novos recursos através das principais bolsas de valores, e para tanto, precisavam se

37 BEDICKS, Heloísa. Os motivos de governança: uma questão de saúde. Disponível em: < http://www.diagnosticoweb.com.br/especiais/os-motivos-da-governanca-uma-questao-desaude.html>. Acessado em 07.07.2010.

${ }^{38}$ Dispositivo legal que impõe boas práticas de conformidade legal, prestação responsável de contas, transparência e senso de justiça. Exige que os principais executivos da companhia confiram os relatórios periódicos entregues à Securities and Exchange Comission (SEC), garantindo assim que esses não contenham informações falsas ou omissas, representando a real situação financeira da companhia, sendo que no caso de divulgações errôneas ou inexatas serão impostas penalidades; proíbe, direta ou indiretamente, inclusive por intermédio de subsidiárias, a oferta, manutenção ampliação ou renovação de empréstimos entre a empresa e quaisquer conselheiros ou diretores; devolução de bônus e/ou lucros em caso de nova publicação de demonstrações financeiras por não cumprimento de exigências relativas ao modo de prestação das informações; limitação aos planos de benefícios dos altos administradores e membros do conselho de administração; padrões de conduta e maior responsabilidade dos advogados, entre outros.

${ }^{39}$ VIANA, Andréa. Governança Corporativa: Um panorama da evolução e das dificuldades das organizações brasileiras de agirem efetivamente em compliance às suas diretrizes. (LATEC/UFF) Disponível em:

https://docs.google.com/viewer?url=http\%3A\%2F\%2Fwww.excelenciaemgestao.org\%2FPortals $\%$ 2F2\%2Fdocuments\%2Fcneg7\%2Fanais\%2FT11_0372_2135.pdf > p. 8, Acessado em 07.10.2012. 
enquadrar e utilizar os mesmos moldes de controles utilizados por multinacionais tais como a Lei Sarbanes-Oxley (SOX).

A visibilidade do Brasil lá fora e os novos patamares alcançados pela economia brasileira com uma série de indicadores macroeconômicos favoráveis, aliados a adoção de melhores práticas de governança estão atraindo mais investidores, e por consequência, fazendo com que o mercado de capitais cumpra seu papel de financiar ideias e projetos.

Paralelamente, há um cenário internacional marcado por forte instabilidade, no qual há saídas repentinas de capital para outros mercados. Neste contexto, a adoção de boas práticas de governança pelas empresas é fundamental para transpor esse momento com os menores impactos negativos possíveis.

Nos últimos anos, houve um avanço da posição do Brasil como referência mundial em boas práticas, mormente no cenário latino americano, no qual o Brasil é referência e promove o tema.

Segundo a superintendente do IBGC, Heloísa Bedicks ${ }^{40}$ houve uma diversificação das formações societárias das companhias no Brasil, que trouxe alterações no sistema de governança dentro do ambiente corporativo. Como houve uma rápida transição, não houve o tempo necessário para a disseminação e real implantação das práticas de governança e, como consequência o poder político pode tornar a gestão muito forte e concentrada sem a consolidação das práticas de governança.

Por este motivo, prossegue a autora, houve consideráveis avanços nas discussões das responsabilidades e expectativas do desempenho dos conselhos de administração, que antes eram visto como certa formalidade, como órgãos acessórios e hoje são mais valorizados pelas companhias e tomam a liderança das decisões estratégicas. Os conselhos de administração devem balizar o poder dos gestores para que estes não tomem decisões desalinhadas com o interesse da companhia e dos acionistas.

\footnotetext{
${ }^{40}$ BEDICKS, Heloísa. Os motivos de governança: uma questão de saúde. Disponível em: < http://www.diagnosticoweb.com.br/especiais/os-motivos-da-governanca-uma-questao-desaude.html>. Acessado em 07.07.2010.
} 
A maior visibilidade do conselho está ligada a necessidade da prática da transparência, além dos princípios de responsabilidade corporativa, prestação de contas e equidade, tendo na governança a criação de valor.

Neste cenário, segundo Heloísa ${ }^{41}$, o Brasil vivenciou um aumento no número de companhias que emitem exclusivamente ações ordinárias e teve uma diminuição no grau de concentração acionária de suas companhias.

Hoje, discute-se a adoção de avaliação de conselheiros e conselho, a necessidade de aprimoramento do seu funcionamento e composição, com determinado nível de diversidade em gênero e qualificações. Há ainda discussões a respeito da instituição de quotas para mulheres e a inclusão de representantes de funcionários em conselho, além da criação de um Comitê de Mercado para Aquisições e Fusões (CAF).

\subsection{Instrução Normativa 480 e 481 da CVM}

O Brasil, avançando nas práticas de divulgação pelas empresas, promulgou, no final de 2009, as Instruções Normativas 480 e 481, pela Comissão de Valores Mobiliários (CVM).

Um dos motivos que levou a CVM a modificar a regulação foi procurar alinhar as informações das companhias nacionais às regras da IOSCO (The Internacional Organization os Securities Commissions). ${ }^{42}$

A Instrução 480 reforma as regras aplicáveis à obtenção do registro de companhias abertas, que antes era disciplinado pela Instrução CVM 202 de 1993, que tinha deficiências como, por exemplo: insuficiência e inadequação das informações disponibilizadas aos acionistas nas Assembleias Gerais e dificuldades de mobilização dos acionistas.

\footnotetext{
41 BEDICKS, Heloísa. Os motivos de governança: uma questão de saúde. Disponível em: < http://www.diagnosticoweb.com.br/especiais/os-motivos-da-governanca-uma-questao-desaude.html>. Acessado em 07.07.2010.

ALMEIDA, Jennifer. RIs debatem as mudanças nas Instruções CVM 480 e 481. Revista RI. n. 141. São Paulo, p. 48. Março 2010.
} 
A Instrução Normativa $480^{43}$ estabelece as regras de registro de emissores de valores mobiliários admitidos à negociação em mercados regulamentados, bem como o regime informacional a que tais emissores estão sujeitos (Formulário de Referência). Dentre os quais pode-se citar: divulgação da remuneração dos administradores, com informações sobre os valores máximo, médio e mínimo pago pela companhia, especificação do montante destinado a remuneração fixa e remuneração variável, detalhar planos de opção e de participação nos lucros, divulgar maior e menor compensação total entre os membros do conselho administrativo, descrição da estrutura acionária da empresa, e divulgação da qualificação dos administradores.

A Instrução Normativa $481^{44}$ regulamenta os pedidos públicos de procuração para o exercício do direito de voto nas assembleias de companhias abertas e as informações que as companhias devem fornecer aos acionistas antes da assembleia. Permitindo aos acionistas acesso a informação com tempo suficiente para tomada de decisões e, facilita os meios para votação a distância em assembleias gerais. Desta forma, estimula o uso da internet para a realização do voto por procuração. As companhias tem agora a opção de adotar um sistema eletrônico capaz de aceitar os pedidos públicos de procuração e receber votos por procuração dos investidores ou reembolsar os custos a estes. Isso reduz significativamente o custo de participação e possibilita maior engajamento do investidor, principalmente o investidor estrangeiro.

Essas resoluções vieram com o objetivo de ampliar a participação dos acionistas nas assembleias, facilitando não só o acesso às informações antes de sua realização, mas também proporcionando ferramentas de votação eletrônicas, agilizando o processo e diminuindo os custos

\footnotetext{
${ }^{43}$ CVM divulga Instrução que estabelece as regras de registro de emissores de valores mobiliários admitidos à negociação em mercados regulamentados. Disponível em: < http://www.cvm.gov.br/port/infos/Comunicado\%20-\%207\%20de\%20dezembro.asp>. Acessado em 08.10.2012.

${ }^{44}$ CVM divulga Instrução sobre informações e pedidos públicos de procuração para exercício do direito de voto. Disponível em: < http://www.cvm.gov.br/port/infos/Comunicado\%20\%2015\%20de\%20dezembro.asp>. Acessado em 10.10.2012.
} 
envolvidos. Facilitando assim, com que o investidor estrangeiro finalmente fique apto a exercer o seu direito de participar das decisões das companhias nas quais investe.

No entanto, essa diminuição de custos só será possível nas empresas que implantarem um sistema de votação à distância, do contrário, as despesas dos investidores participantes das assembleias deverão ser reembolsadas pela empresa.

\subsection{Os atuais problemas de Governança nas empresas brasileiras}

Segundo Alexandre Di Miceli ${ }^{45}$, a governança corporativa tem basicamente dois objetivos numa empresa: fazer com que sejam tomadas as melhores decisões de negócio para a empresa, no longo prazo; e assegurar a conformidade para com as leis, regulamentações e políticas internas de forma alinhada com os valores considerados fundamentais para a empresa. A questão reside em como fazer isso acontecer nas empresas.

Segundo o autor, a visão tradicional da Governança sempre falou muito em mecanismos de incentivo e controle, colocando o incentivo sobre a forma de sistemas de remuneração, ou mecanismos de avaliação de desempenho, ou estabelecendo controles e monitoramentos tais como auditorias, conselhos de administração, e fiscalização por agentes externos à empresa, entre outros. No entanto, a Governança Corporativa não se resume a esses fatores, vai muito além deles.

O autor discorre que a Governança deve ser entendida no âmbito do contexto social das empresas. As pessoas que trabalham nessas empresas agem de acordo com a sua consciência, desta forma, deve-se fomentar uma atitude mais consciente nas pessoas, a empresa deve cuidar desta conscientização. Mas como a empresa fomentaria as atitudes mais corretas?

\footnotetext{
45 MICELLI, Alexandre. Novos intérpretes, n.18, abril 2012. Disponível em: $\langle$ http://www.luzio.com.br/novos-interpretes.php?id=52394cf47127e93a6331d989c51955b7>. Acessado em 21.09.2012.
} 
Alexandre Di Miceli frisa que existem aspectos que são chave: o primeiro é o exemplo da liderança, que o ser humano tende a imitar comportamento, desta forma, o indivíduo vai olhar para seu superior e tenderá a imitar seu comportamento. Quando ele observa o líder se comportando de tal maneira, ele tenderá a replicar esse comportamento. Desta forma, se for um líder que prega valores éticos e na prática não age assim, as pessoas irão absorver esse comportamento. Por outro lado, se as pessoas acreditam e veem que ele vai agir no melhor interesse da companhia, isso de certa forma irá ajudar as pessoas a agirem da mesma forma.

O segundo aspecto é o contexto, quando se está em um ambiente onde há solidariedade, onde todos se ajudam e visam o melhor para a companhia, há uma tendência que essa atitude seja refletida nas outras pessoas, contagie. No entanto, ambientes muito agressivos, onde cada um somente enxerga seu ganho pessoal, os outros colegas de trabalho se sentirão à vontade para agir assim também.

Além disso, é muito comum que as empresas tenham um Código de Ética e Conduta que não é internalizado pelas pessoas, não há atenção para este código, portanto deve-se fomentar a adesão dessas pessoas a este lado intangível que é fundamental dentro da boa Governança Corporativa. Desta forma, haverá empresas mais perenes tomando decisões melhores no longo prazo.

Há uma tendência no Brasil de enxergar a Governança Corporativa como um conjunto de requisitos a serem cumpridos, uma espécie de checklist que deve ser satisfeito para obedecer a exigências externas. Isso tem ocorrido em algumas empresas e com relação a agentes do mercado. Todavia, tal modelo foge ao propósito básico da Governança Corporativa, que é o de fazer com que atitudes dentro da empresa reflitam objetivos centrais da Governança como, por exemplo: introduzir discussões sobre o que é melhor em termos de Conselho de Administração, de avaliação de desempenho, de ambiente meritocrático, gerenciamento de riscos, 
transparência nas relações entre os agentes públicos internos e externos e sustentabilidade da empresa, de forma a evitar surpresas desagradáveis no futuro.

Atualmente, no Brasil, há várias formas organizacionais diferenciadas entre as maiores empresas do país: há empresas com controle compartilhado, no qual alguns poucos acionistas controlam a companhia de forma conjunta; há também o controle pulverizado (BM\&FBovespa ${ }^{46}$ ); além das empresas com controle estatal (Petrobrás) e até familiar (Itaú).

Sendo assim, não há um modelo pré estabelecido possível de ser aplicado em todas as empresas. Há de se perceberem as variações, a forma como a companhia é controlada, sua estrutura acionária, para que melhor se possa compreender as questões-chave que a empresa terá que enfrentar. Além disso, não é possível aplicar o Código do IBGC de forma compulsória em uma empresa, pois cada uma tem seus desafios próprios de Governança, sendo necessário entender a empresa para que se possa adequar a Governança aquela realidade específica.

\subsection{Aspectos a serem obervados no Conselho de Administração}

Como já mencionado anteriormente, a governança é de fato exercida pelo Conselho de Administração e pela diretoria executiva. Em face disto, o Conselho de Administração se tornou o foco das reformas de governança corporativa, dentre as quais estão: a separação das funções de presidente executivo e presidente do conselho de administração; o aumento da independência e da cota de responsabilidade do conselho de administração ${ }^{47}$ e o controle da remuneração dos altos executivos ${ }^{48}$.

\footnotetext{
${ }^{46}$ A BM\&FBovespa é fruto da fusão que ocorreu em 2008 entre a BM\&F (Bolsa de Mercadorias e Futuros) e a Bovespa. Atualmente a BF\&FBovespa é o único centro de negociações de ações no Brasil e o maior da América Latina.

${ }^{47}$ GALBRAITH, Jonh Kenneth. A economia das fraudes inocentes: verdades para o nosso tempo. Tradução de Paulo Anthero Soares Barbosa. São Paulo. 2004, p.36.

${ }^{48}$ QUATERLY, McKinsey. 3 reformas para a governança. Revista HSM Management, n. 47, Novdez 2004, São Paulo: Savana, p. 50-58.
} 
Segundo Miceli ${ }^{49}$, um sistema no qual o Presidente de uma empresa avalia diferentes opções a serem seguidas, toma decisões, implementa, se avalia e se monitora é um sistema fadado a ter problemas.

Em empresas familiares é muito comum que o Conselho de Administração seja um contrapeso a uma liderança totalmente inquestionável. No entanto, não é suficiente que haja essa liderança inquestionável, pois a empresa vai atingir um determinado porte no qual adquire tamanha complexidade onde não vai ser possível conhecer todas as estratégias de marketing, gestão de pessoas, investimentos, finanças e estratégia geral. Desta forma, prossegue o autor, é necessário reunir pessoas que tenham diferentes conhecimentos, o que levará a melhores decisões do que aquelas tomadas individualmente.

Não obstante, há de se observar determinados vieses comportamentais que ocorrem e poucas pessoas conseguem ser perspicazes a eles, e que, no entanto, são muito importantes. Alexandre cita o exemplo de que existe uma vasta literatura que identifica que os empreendedores são muito propensos a sofrerem excesso de confiança e de otimismo. Assim, numa projeção de mercado em que as chances de fracasso estão em $50 \%$ (cinquenta por cento), na visão deste empreendedor a taxa de fracasso é de $5 \%$ (cinco por cento). E é aí que está o papel do Conselho de Administração.

Adicionalmente o Conselho deve fazer perguntas difíceis a fim de verificar se a gestão está atuando de acordo com todos os regramentos, leis, e regulamentos exigidos; se não está gerando passivos futuros ocultos para aquela companhia; avaliar se aquelas pessoas são as melhores para estarem na gestão; e se a gestão diária vem promovendo um ambiente meritocrático.

Uma grande preocupação atual com a governança está na discrepância entre a Governança que as empresas pregam ter e na que elas realmente têm. Muitas empresas desejam ter a melhor governança possível,

\footnotetext{
49 MICELI, Alexandre. Novos intérpretes, número 18, abril 2012. Disponível em: 〈http://www.luzio.com.br/novos-interpretes.php?id=52394cf47127e93a6331d989c51955b7〉. Acessado em 21.09.2012.
} 
no entanto, não querem mudar nada na estrutura de seu funcionamento. Essas empresas desejam possuir os títulos e a boa imagem pública em termos de Governança, e acabam não mudando nada na sua rotina diária.

Muitas empresas divulgam em seus websites que possuem determinada estrutura em termos de Governança quando a situação real não corresponde ao publicado. Infelizmente, ainda não há nenhum processo de auditoria sendo realizado no Brasil de forma a acompanhar a validade dos processos de Governança.

\subsection{Maiores equívocos observados no Conselho de Administração no Brasil}

Há uma tendência de que os problemas relacionados ao Conselho de Administração nas empresas brasileiras sejam bem similares em diversas empresas.

Pode-se citar como exemplo de que costuma-se confiar demais e exclusivamente nas informações vindas do gestor que cria a pauta do próprio Conselho. Desta forma, ele proporá temas que ele considera pertinentes, omitindo outros. Assim, o conselheiro externo tende a confiar na pauta elaborada, partindo de um princípio de que este gestor conhece a empresa melhor que ninguém, e acaba acatando as ideias dessa pessoa sem questionar muito, sem pedir outras informações internas.

No entanto, isso pode gerar problemas seríssimos, como ocorreu no caso da Parmalat, no qual o fundador da empresa que estava lá há 40 anos era o Diretor-Presidente e Presidente do Conselho de Administração. Os outros conselheiros confiavam cegamente no que ele dizia, sem maiores questionamentos.

Assim, o correto é que o conselheiro seja pró-ativo, e procure outras fontes de informações e esteja em contato com outras pessoas.

Um ponto de destaque e em relação ao qual há muita queixa nos Conselhos de Administração no Brasil, é o baixo nível de engajamento de 
muitos conselheiros, que não participam das discussões, apenas dizem aprovo ou me abstenho. Ainda existem, até mesmo, conselheiros que entram e saem sem falar nada nas reuniões.

Outras vezes o conselheiro independente é escolhido quando o acionista sabe que ele não vai dar problema ou levantar questionamento nas reuniões. ${ }^{50}$

Há também o equívoco relacionado à tendência, quando se procura pessoas parecidas para compor o Conselho, o que acaba prejudicando um ambiente de diversidade, que é fundamental para um bom Conselho. É necessário que haja diversidade em sua composição no que tange a aspectos como, por exemplo, formação, idade, gênero e visões de mundo. Afinal de contas, para que haja efetividade nas decisões de um Conselho deve haver diversidade na composição de seus membros, para que não se exclua as visões externas que sejam diferentes e que tendem a acrescentar.

Pessoas com visões diferentes podem não entender de determinados assuntos com profundidade, no entanto, irão trazer para a empresa uma visão mais aberta, fora do cotidiano da empresa e útil em longo prazo. Por isso é importante também não ter pessoas somente do próprio setor de atuação da companhia.

Um aspecto importante é que o conselheiro não pode pensar da mesma forma que o executivo. $\mathrm{O}$ conselheiro não pode ser a mesma pessoa que está dirigindo; isso dificulta a tomada das melhores decisões, e acaba fugindo do objetivo do Conselho que é proteger e valorizar o patrimônio dos acionistas no longo prazo.

Há também uma outra falha, que ocorre quando se prioriza dentro de um Conselho o aspecto relacionado à composição deste, e não ao seu funcionamento. Para muitas empresas, basta ter Conselheiros que são reconhecidos no mercado, e o problema já está resolvido. Mas pelo

\footnotetext{
${ }^{50}$ IBGC e Booz\&co. Panorama da Governança Corporativa no Brasil. Disponível em: < http://www.google.com/url?sa=t\&rct=i \&q=\&esrc=s\&source=web\&cd=1\&ved=0CCAQFjAA\&url =http\%3A\%2F\%2Fwww.ibgc.org.br\%2FDownload.aspx\%3FRef\%3DPesquisaConhecimento\%26 CodPesquisa\%3D20\&ei=ZfKFUMnCCYzU0gHC14DgCg\&usg=AFQjCNF0vekYOxJZfGzegwN a4k1FPg3pUw\&sig2=B 5DH7ic9_D4tiaTUlfYag > p.17. Acesso em 25.09.2012.
} 
contrário, isso não adianta. O Conselho deve funcionar bem, independentemente de sua composição. Muitas vezes existem pessoas com menos destaque no cenário nacional, que terão mais tempo, irão se dedicar mais e fazer com que o Conselho funcione melhor, afirma Alexandre Di Miceli. ${ }^{51}$

Também o que pode ser observado como um problema muito frequente nos Conselhos no Brasil, principalmente nas empresas de controle compartilhado, é que quando uma pessoa é indicada por alguém, esta pessoa considera que deve representar os interesses de quem a escolheu, em detrimento do interesse da companhia como um todo. Isto leva a um desastre, pois gera muitos conflitos. Em empresas com controlador definido, as pessoas indicadas pelo controlador incorporam uma ideia de que precisam defendê-lo. O mesmo acontece com aquele que é indicado pelo minoritário, que considera que deve defender a posição específica daquele acionista.

Deve-se observar também um aspecto muito comum no Brasil, relacionado à informalidade do Conselho. Costuma-se montar os Conselhos sem regimentos, sem comitês, reuniões sem registro em ata; as reuniões não são marcadas com antecedência, o material distribuído para análise não tem qualidade informativa. Esses fatores comuns contribuem para que o órgão não funcione bem. É preciso que a clareza seja uma de suas principais regras de funcionamento.

Ainda há de haver um enorme avanço no que diz respeito aos Conselhos. Estes precisam ter uma visão menos voltada para dentro, e mais voltada para fora. As reuniões não podem ter como foco principal as cobranças financeiras, fato que muitas vezes acaba ocorrendo. Os temas que são muito estratégicos para uma empresa, embora não tão urgentes, como por exemplo, avaliação de desempenho, gestão de riscos, sucessão do Diretor-Presidente, política de remuneração, dentre outros, precisam ter

\footnotetext{
51 MICELLI, Alexandre. Novos intérpretes, n. 18, abril 2012. Disponível em: $\langle$ http://www.luzio.com.br/novos-interpretes.php?id=52394cf47127e93a6331d989c51955b7 >. Acessado em 21.09.2012.
} 
espaço e ser profundamente discutidos, e não podem ser sempre deixados de lado em virtude das questões mais imediatas do dia a dia.

Tem-se observado também, que os conselheiros não dedicam a devida atenção e o devido tempo exigidos a um cargo com tamanha responsabilidade. Muitos não tem nem a ideia clara dos passivos legais aos quais estão sujeitos. Segundo Alexandre Di Miceli, há quatro atributos legais que um conselheiro precisa ter: independência de pensamento, que decorre do fato de suas decisões serem pautadas no que é melhor para a empresa, e não nos interesses do empreendedor que o convidou; qualificação, de forma que ele deve entender dos assuntos básicos; incentivos; interesse pela empresa; disponibilidade de tempo e dedicação.

\subsection{O preenchimento do Formulário de referência pelas companhias}

A instrução normativa 480 da $\mathrm{CVM}^{52}$ proporcionou um grande avanço no que tange a qualidade das informações prestadas aos investidores por meio do formulário de referência. Em substituição ao formulário de Informações Anuais (IAN) surge o formulário de referência com o objetivo de ser um documento extremamente detalhado, capaz de transmitir aos investidores segurança, sendo considerado como o principal instrumento de comunicação para publicação da prestação de contas da companhia a todo o público alvo, visto que se trata de uma ferramenta onde devem estar reunidas informações relevantes para compreensão e avaliação da companhia e dos valores mobiliários por ela emitidos. ${ }^{53}$

Em adição, discorre Andréa Souza Viana que a forma como a informação é prestada pode ter reflexos diretos nos resultados e na

\footnotetext{
52

CVM.

Disponível

<http://www.cvm.gov.br/asp/cvmwww/atos/exiato.asp?File=\%5Cinst\%5Cinst480.htm

em: Acessado em 12.09.12.

${ }^{53}$ VIANA, Andréa. Governança Corporativa: Um panorama da evolução e das dificuldades das organizações brasileiras de agirem efetivamente em compliance às suas diretrizes. (LATEC/UFF) Disponível em:

https://docs.google.com/viewer?url=http\%3A\%2F\%2Fwww.excelenciaemgestao.org\%2FPortals\% 2F2\%2Fdocuments\%2Fcneg7\%2Fanais\%2FT11_0372_2135.pdf > p. 8, Acessado em 07.10.2012.
} 
valorização das ações das companhias. No entanto, para que o formulário seja útil aos investidores, deve haver uma cooperação por parte da companhia, de forma a fornecer informações de forma adequada. Entretanto, isso não vem ocorrendo da forma que deveria.

Há um sério problema de transparência nas questões de governança quando do preenchimento do formulário. As empresas fornecem apenas o mínimo necessário de informações exigido por lei, desta forma, o valor de informação obtido pelos formulários tem sido muito baixo, o que caracteriza pouca boa vontade ou falta de maturidade na prestação de contas por parte das companhias.

Algumas companhias fornecem respostas estapafúrdias, outras chegam até mesmo a copiar parágrafos do estatuto social que não guardam absolutamente nenhuma relação com a pergunta feita.

Ocorre que esse comportamento acaba dificultando a percepção, pelos investidores, de como as empresas vêm funcionando.

Podemos citar alguns exemplos: o item 13.5 do formulário de referência, item muito importante, visto que permite entender os interesses econômicos e poderes políticos nas mãos dos administradores, de forma que requer às companhias a divulgação da quantidade dos valores mobiliários detidos por membros do Conselho de Administração, Diretoria ou Conselho Fiscal. Muitas empresas responderam esse ponto como "não aplicável", inclusive uma empresa que pertence ao Novo Mercado respondeu "não houve". Interessante seria entender o que não houve.

Outro exemplo é o item 13.11, sobre a remuneração dos principais órgãos sociais. Essa questão já gerou muita polêmica. Um percentual de $25 \%$ (vinte e cinco por cento) das empresas não divulgou essa informação justificando que haviam sido liberadas de preencher essa questão devido ao processo movido pelo Instituto Brasileiro de Executivos de Finanças do Rio de Janeiro (Ibef - RJ). No entanto, muitas das empresas que responderam deram respostas que não faziam o menor sentido, isso quando não respondiam "não aplicável". Como exemplo, uma empresa divulgou 
remuneração média anual de $\mathrm{R} \$ 375$ mil (trezentos e setenta e cinco mil) aos diretores, quando todavia limitara a remuneração máxima em $\mathrm{R} \$ 51,6$ mil (cinquenta e um vírgula seis mil).

Outra afirmou que a remuneração de todos os diretores seria $\mathrm{R} \$ 2,45$ milhões (dois vírgula quarenta e cinco milhões), sendo no total seis diretores. Curiosamente, a companhia reportou lucro líquido de $\mathrm{R} \$ 3,8$ milhões (três vírgula oito milhões). O que leva ao questionamento sobre se não estariam os diretores sendo excessivamente bem remunerados?

Há também um item muito importante, qual seja: o currículo dos administradores, que permite ao investidor verificar se determinado administrador possui a capacidade e conhecimentos necessários para atuar na alta gestão de uma companhia aberta. Item este também que não vem recebendo a devida atenção.

Grande parte das empresas não presta informações importantíssimas a respeito da carreira, educação e cargos ocupados em outras companhias.

Desta forma, tendo em vista a grande falta de compromisso das companhias na prestação das informações, deveria haver maior fiscalização por parte da CVM, devendo-se detalhar melhor o que deve ser divulgado.

Também não se pode esquecer que deveria haver pressão por parte dos investidores. É uma pena, porém, que até hoje não houve queixas públicas ou estruturadas sobre essa falta de maturidade das empresas ao prestar suas contas.

Tendo em vista que as pessoas físicas não leem esses documentos, talvez por uma falta de cultura por parte do brasileiro em fazer esse tipo de averiguação, e também por muitos investidores institucionais fazerem parte do bloco de controle dessas empresas, não há boas perspectivas para mudar esse quadro.

Infelizmente, não tem havido a transparência necessária nas informações de governança que seriam esperadas quando criado o 
Formulário de Referência. Uma pena, pois o Formulário de Referência é uma ferramenta da CVM que representou um grande avanço.

As empresas precisam elaborar seus Formulários de Referência com estratégia e não por obrigação, e aproveitar suas AGO (Assembleia Geral Ordinária) para dialogar com um publico maior que o acionista. Assim, elas estarão sendo longevas ${ }^{54}$.

\subsection{Dados da evolução da Governança no Brasil}

Alexandre Di Miceli da Silvera ${ }^{55}$ realizou pesquisa sobre a evolução dos Conselhos de Administração no Brasil e no mundo, publicada no ano de 2012 pelo IBGC, no qual foi constatado o seguinte no que tange a mudanças nos Conselhos de Administração no Brasil de 2001 até 2011:

\begin{tabular}{|l|c|c|c|}
\hline \multicolumn{1}{|c|}{ Tema } & 2001 & 2006 & 2011 \\
\hline $\begin{array}{l}\text { Separação cargos Diretor } \\
\text { Presidente e Presidente do } \\
\text { Conselho de Administração }\end{array}$ & $70 \%$ & $77 \%$ & $91 \%$ \\
\hline$\%$ Conselheiros Considerados independentes & $9 \%$ & $18 \%$ & $25 \%$ \\
\hline \% Conselheiros eleitos por minoritários & $10 \%$ & $16 \%$ & $24 \%$ \\
\hline Tamanho do Conselho de Administração & 8,7 & 8,9 & 9,2 \\
\hline
\end{tabular}

\footnotetext{
${ }^{54}$ GONZALEZ, Roberto. Sustentabilidade. Instruções 480 e 481: Um caminho para só relato e a voz do público estratégico.Revista RI. Rio de Janeiro: IMF Editora Ltda. Março 2010, p. 25.

55 MICELI, Alexandre. A evolução dos Conselhos de Administração no Brasil e no mundo. Disponível em: $<$ http://www.google.com/url?sa=t\&rct=j\&q=\&esrc=s\&source=web\&cd=2\&ved=0CCUQFjAB\&u rl=http\%3A\%2F\%2Fwww.ibgc.org.br\%2FDownload.aspx\%3FRef\%3DEventos\%26CodArquivo \%3D333\&ei=A FUNuSEPSa0gHM_oHoDw\&usg=AFQjCNGqczRDMIdVU5aTCQ4N6kelL011 Q\&sig2=hGSBOscIzIIrq2E_yoi9Rg $>$. Acessado em 12.09.2012.
} 


\begin{tabular}{|l|c|c|c|}
\hline Número de Comitês do Conselho de Administração & 0,4 & 1,1 & 1,7 \\
\hline $\begin{array}{l}\text { \% Empresas com Comitê de Auditoria do Conselho de } \\
\text { Administração }\end{array}$ & $8 \%$ & $21 \%$ & $35 \%$ \\
\hline $\begin{array}{l}\text { \% Empresas com Comitê de Remuneração do } \\
\text { Conselho de Administração }\end{array}$ & $13 \%$ & $23 \%$ & $44 \%$ \\
\hline $\begin{array}{l}\text { Número de reuniões por ano do Conselho de } \\
\text { Administração }\end{array}$ & 7,5 & 8,8 & 9,9 \\
\hline
\end{tabular}

Percebe-se que houve uma considerável evolução na importância dada pelas empresas em aderir às práticas recomendadas para uma boa governança corporativa.

A pesquisa realizada também constatou que a expectativa da sociedade em relação ao papel do Conselho de Administração que antes era baixa, sendo os Conselhos vistos somente como órgão figurativo, passou a ser elevada, e a visão sobre o Conselho de Administração passou a ser de os responsáveis em última instância pelos resultados e riscos das companhias.

A empresa Booz \& Company e o IBGC ${ }^{56}$ realizaram ao longo de 2009 uma pesquisa para levantar o panorama atual da Governança Corporativa no Brasil, comparando com a situação de 2003, quando havia sido realizado um primeiro estudo sobre o perfil da Governança no Brasil. Desta pesquisa obteve-se as seguintes conclusões:

i. Houve um aumento significativo da atenção dos conselheiros com o gerenciamento dos riscos estratégicos, que pode ter ocorrido em virtude das perdas de valor que ocorreram recentemente;

ii. Apesar dos mecanismos existentes, o acompanhamento das decisões tomadas ainda é considerado insuficiente pelos conselheiros;

\footnotetext{
${ }^{56}$ IBGC e Booz\&co. Panorama da Governança Corporativa no Brasil. Disponível em: < http://www.google.com/url?sa=t\&rct=i \&q=\&esrc=s\&source=web\&cd=1\&ved=0CCAQFjAA\&url $=$ http\%3A\%2F\%2Fwww.ibgc.org.br\%2FDownload.aspx\%3FRef\%3DPesquisaConhecimento\%26 CodPesquisa\%3D20\&ei=ZfKFUMnCCYzU0gHC14DgCg\&usg=AFQjCNF0vekYOxJZfGzegwN a4k1FPg3pUw\&sig2=B 5DH7ic9 D4tiaTUlfYag >. Pág 17. Acesso em 25.09.2012.
} 
iii. O papel do conselheiro está evoluindo de fiscalização para agregação de valor para a empresa;

iv. A maior parte dos Conselhos pesquisados conta com o apoio de Comitês de Assessoramento;

v. A avaliação dos Conselhos permanece como uma prática pouco frequente pelas empresas especializadas. Além disso, as pessoas relutam muito em avaliar e serem avaliadas;

vi. A importância do treinamento dos conselheiros evoluiu, mas sua relevância para a efetividade da Governança ainda é questionada;

vii. A divulgação da remuneração do Conselho de Administração é vista como não indicada nas empresas pesquisadas, sob a alegação de resulta em risco para os conselheiros;

viii. A participação dos minoritários evoluiu, mas ainda é bastante baixa. As convocações são feitas, mas poucos minoritários comparecem. Além disso, apesar de haver representante dos minoritários, há reuniões prévias dos controladores onde de fato são tomadas as decisões;

ix. A definição da pauta das reuniões, a qualidade das informações disponibilizadas e principalmente a dinâmica das contribuições na discussão apresentaram resultados piores quando comparados ao estudo de 2003.

Também podemos citar a pesquisa realizada pela Price Waterhouse and Coopers em parceria com a Fundação Dom Cabral, e publicada em outubro/2011, com cerca de 400 entrevistados, entre eles: acionistas controladores e minoritários, conselheiros, CEOs, investidores institucionais, bancos comerciais e de investimentos, reguladores e representantes de agências de rating. 
No que se refere à maturidade e aperfeiçoamento do mercado de capitais brasileiro em relação à governança corporativa que foi constatado na pesquisa, podemos $\operatorname{citar}^{57}$.

i. Entre os entrevistados é unânime a opinião de que a qualidade de gestão das empresas avançou muito com a maior transparência, maior espaço aos acionistas minoritários e mais clareza nos números divulgados. Os resultados podem ser percebidos na valorização das ações dessas empresas em comparação com aquelas que ainda não adotaram essas práticas $^{58}$.

ii. Foi detectado elevado nível de insatisfação ( $41 \%$ - quarenta e um por cento) com relação à clareza de comunicação das estratégias. Embora, mais de $70 \%$ (setenta por cento) dos entrevistados consideram satisfatório/muito satisfatório o nível de informações recebidas antes das assembleias, assim como as práticas correntes na preparação e condução das reuniões de acionistas 59 .

iii. Os entrevistados manifestaram insatisfação com a eficácia dos Conselhos de Administração na prevenção e gestão de riscos, 51\% (cinquenta e um por cento) deles estão insatisfeitos ou muito insatisfeitos e $34 \%$ (trinta e quatro) não estão satisfeitos com o grau de independência dos Conselhos Fiscais ${ }^{60}$.

iv. Entre os entrevistados, $52 \%$ (cinquenta e dois por cento) estão satisfeitos com a legislação vigente e $48 \%$ (quarenta e oito por cento) acham que ela não é satisfatória. Quando questionados sobre as punições aplicadas nos casos de violação das leis, no entanto, há uma clara definição. Quase a metade dos stakeholders, 47\% (quarenta e sete) não está satisfeita com as sanções aplicadas nos casos de fraude. Esses resultados permitem

\footnotetext{
${ }^{57}$ PRICEWATERHOUSECOOPERS, Auditores Independentes. Governança Corporativa: um processo em evolução no Brasil, 2011. Disponível em: < http://www.pwc.com.br/pt BR/br/publicacoes/assets/gov-corporativa-11.pdf >. Acesso em 26.10.2012.

${ }^{58}$ Ibid. p. 2.

${ }^{59}$ Ibid. p. 3 .

${ }^{60}$ Ibid. p. 4.
} 
supor que se houvesse maior rigor nas punições, o controle seria mais eficiente $^{61}$.

v. A pesquisa acende o sinal amarelo em relação às opiniões manifestadas pelos Conselhos. Além da insatisfação dos stakeholders com a capacidade dos membros dos conselhos de antecipar riscos, 55\% (cinquenta e cinco) deles não acreditam que os conselheiros estejam suficientemente preparados para compreender as frequentes mudanças contábeis e os riscos que elas representam. O mercado brasileiro evoluiu bastante em relação à gestão de riscos, mas as empresas ainda carecem de maior agilidade nesse aspecto para enfrentar as diversas ameaças, especialmente aquelas que provocam mudanças repentinas de cenários ${ }^{62}$.

vi. Entre os escritórios de advocacia, há predominantemente insatisfação quanto à frequência da utilização de arbitragem como forma de solução de conflitos, com o nível de punição de falhas na aplicação da governança. Na opinião deles, as câmaras de arbitragem não são eficazes ao punir as falhas na aplicação dos preceitos da Governança Corporativa. ${ }^{63}$

\footnotetext{
${ }^{61}$ PRICEWATERHOUSECOOPERS, Auditores Independentes. Governança Corporativa: um processo em evolução no Brasil, 2011. Disponível em: < http://www.pwc.com.br/pt_BR/br/publicacoes/assets/gov-corporativa-11.pdf >. Acesso em 26.10.2012.

62 Ibid. p. 6.

${ }^{63}$ Ibid. p. 14.
} 


\section{Capítulo 4: O Novo Mercado da Bolsa de Valores de São Paulo (BOVESPA) como um dos principais fomentos à governança corporativa no Brasil.}

Em 1997 a Bovespa contratou uma equipe, chefiada pelo economista José Roberto Mendonça de Barros, a fim de obter recomendações de como tirar o mercado de capitais da crise. Naquela época o cenário era de um mercado de ações estagnado, os investidores estavam desestimulados, haviam classes privilegiadas de empresários que concentravam poder e renda.

Em 1999, o estudo, chamado de "Desafios e oportunidades para o mercado de capitais brasileiro" acusou a fragilidade dos direitos dos minoritários, verificada no antagonismo entre um terço de ações ordinárias e dois terços de preferenciais, fato que precisava ser combatido.

Constatou-se que a qualidade das ações oferecidas em bolsa não correspondia às expectativas ou exigências dos investidores, dada a falta de transparência e equidade no tratamento aos acionistas minoritários. Bem como, o fato de que várias companhias que já adotavam boas práticas de governança corporativa não recebiam o merecido reconhecimento pela qualidade de suas práticas, uma vez que estavam misturadas a companhias com práticas inadequadas ou inexpressivas nessa área. ${ }^{64}$

Segundo Calixto Salomão: "a conjunção desses problemas e sua contínua não solução por sucessivas mudanças na lei societária motivaram a busca por soluções não institucionais. Em um movimento interessante [...] a mudança foi de uma solução institucional para a contratual. ${ }^{65} \mathrm{O}$ movimento em sentido inverso é a clara demonstração da captura dos órgãos legislativos pelos grupos mais influentes e poderosos. Paralisadas as instâncias institucionais, sobra aos particulares, convencidos da necessidade

\footnotetext{
${ }^{64}$ MAGALHÃES, Letícia. Governança Corporativa: Sua evolução e a iniciativa brasileira do Novo Mercado da Bolsa de Valores. Nova Lima, 2007, p.88. Dissertação (Mestrado)Curso de direito da Faculdade de Milton Campos.

${ }^{65} \mathrm{O}$ autor quando se refere a "solução contratual", fala do Novo Mercado.
} 
de ética e da aplicação de princípios cooperativos para sobreviver, implementá-los por via contratual. ${ }^{66}$

Tendo em vista esse fato, a Bolsa se inspirou em várias experiências bem-sucedidas de outros países. O Neur Markt, na Alemanha, caracterizado por regras rígidas de proteção aos investidores e transparência, é o melhor exemplo. Além dele, operam também com destaque: o Noveau Marché, na França; o AIM (Alternative InvestmentMarket), em Londres; além de outros mercados menores em Portugal, Espanha, Japão e Itália. ${ }^{67}$ Esses mercados foram criados com o objetivo de atrair companhias de setores de rápido crescimento, como é o caso das companhias de alta tecnologia, telecomunicações, mídia, biotecnologia, etc.

Ribeiro Neto e Fama $^{68}$ expõem a criação do Neur Markt na Alemanha:

“O Neur Markt surgiu em 1997, como uma reação da bolsa alemã a enorme concentração do mercado principal, $70 \%$ (setenta por cento) do volume negociado era de apenas 10 ações. Assim, as empresas alemãs que queriam obter fundos recorriam direto ao Nasdaq americano. Os bancos de investimento não apoiaram o Neur Markt no começo, pois achavam que o tamanho das operações não seria interessante, não visualizam ganhar recursos com esse segmento. Exceção feita a alguns bancos menores alemães. Com o sucesso do mercado, todos passam a se interessar."

Os investidores individuais e institucionais rapidamente reagiram bem às novas regras, e os preços das ações listadas no Neuer Market registraram valorização de $100 \%$ (cem por cento) após três anos de bons

\footnotetext{
${ }^{66}$ SALOMÃO FILHO, Calixto. O novo direito societário, 2 ed., São Paulo: Malheiros, 2002. 58 p. ${ }^{67}$ FERREIRA, Patrícia; SILVA, Sabrina; SILVA, Antônio. Governança Corporativa e o Novo Mercado: uma estratégia de capitalização para o setor sucroalcooleiro. Disponível em: $<$ https://docs.google.com/viewer?url=http $\% 3 \mathrm{~A} \% 2 \mathrm{~F} \% 2 \mathrm{Fwww}$.ead.fea.usp.br\%2Fsemead\%2F9sem ead\%2Fresultado_semead\%2FtrabalhosPDF\%2F326.pdf>. Acessado em 06.10.2012.

${ }^{68}$ RIBEIRO NETO, R. M.; FAMÁ, R. Uma alternativa de crescimento para o mercado de capitais brasileiro - o novo mercado. In: V SEMEAD, 2001, São Paulo.
} 
resultados. No entanto, em 2003, o Neuer Market foi fechado em decorrência da constatação de fraudes ${ }^{69}$.

E após esses estudos, em 2000, a bolsa lançou o Novo Mercado (resoluções 264 e 265 de $1^{\circ}$ [primeiro] de dezembro de 2000), e para facilitar e preparar o processo gradual de adequação das empresas as novas práticas corporativas, criou os níveis diferenciados de governança corporativa - Nível 1 e Nível 2.

Este segmento constitui fator determinante para a avaliação do grau de proteção ao investidor, que influencia sua percepção de risco e o custo do capital da empresa. Com isso, pretende-se conferir maior credibilidade aos investimentos realizados em Bolsa, pois reúne ações de companhias que a princípio, oferecem um nível de risco inferior ao das demais ${ }^{70}$.

Estar listado em um dos seguimentos especiais de Governança Corporativa revela o comprometimento das companhias que a eles voluntariamente aderem em adotarem melhores práticas de governança, a partir da implementação em suas estruturas societárias de regras mais rígidas do que aquelas previstas na legislação brasileira ${ }^{71}$.

Desta forma, objetivou a Bovespa proporcionar ao mercado ambientes de negociação que atraíssem o interesse dos investidores e que paralelamente, valorizassem as companhias nele listadas. Assim, começou a ser reconhecido que a listagem das empresas nos seguimentos especiais "tem impacto sobre a valoração das ações, aumenta o volume de negociação, aumenta a liquidez"72.

A consequência esperada da implementação no Novo mercado e aos Níveis 1 e 2 é fazer com que as ações emitidas pela companhia sejam

\footnotetext{
70 ALMEIDA, Caroline. Governança Corporativa: Arbitragem, administração de conflitos societários e desenvolvimento econômico e social. Dissertação(Programa de Pós Graduação em Direito) do Centro de Ciências Jurídicas e Sociais da Pontifícia Universidade Católica do Paraná, Curitiba, 2007, p.140.

${ }^{71}$ EIZIRIK, Nelson; GAAL, Ariádna B.; PARENTE, Flávia; HENRIQUES, Marcus de Freitas. Mercado de Capitais - Regime Jurídico. Rio de Janeiro: Editora Renovar. 2008, p.230

72 CARVALHO, Antonio Gledson. Efeitos de Migração para os Níveis de Governança da Bovespa. Disponível em: < HTTP://www.bmfbovespa.com.br/pt-br/abmfbovespa/download/uspniveis.pdf>, acessado em 03.09.2012.
} 
mais atrativas para os investidores, tendo em vista que "a passagem para um patamar superior de governança aumenta o grau de segurança oferecido aos acionistas, bem como melhora a qualidade de informações prestadas pelas empresas. O resultado esperado seria a menor volatilidade das ações e os retornos acima da média do mercado". ${ }^{73}$

Osmar Corrêa Lima destaca que “os próprios agentes do mercado parecem ter se conscientizado da importância e da força do acionista minoritário (não-controlador) para o desenvolvimento da economia nacional" 74 .

Maria Helena Santana ${ }^{75}$ destaca como principais benefícios pelas empresas à adoção das melhoras práticas de governança:

i. Melhora da imagem institucional

ii. Maior visibilidade

iii. Maior demanda pelas ações

iv. Valorização das ações

v. Menor custo do capital

Já para os investidores:

i. Maior precisão na precificação das ações

ii. Melhora do processo de acompanhamento e fiscalização

iii. Maior segurança quanto aos seus direitos societários

iv. Redução de risco para o país

v. Canalização de mais poupança para a capitalização das companhias

vi. Investimentos mais seguros e diversificados

Em fevereiro de 2002, houve o primeiro registro no Novo Mercado com o $I P O^{76}$ da Companhia de Concessões Rodoviárias (CCR), deste fato,

\footnotetext{
${ }^{73}$ VIEIRA, Solange Paiva; MENDES, André Gustavo Salcedo, "Governança Corporativa: Uma análise de sua evolução e Impactos no Mercado de Capitais Brasileiro", Revista BNDES, Rio de Janeiro, número 22, dez. 2004, p. 110.

${ }^{74}$ CORRÊA LIMA, Osmar Brina. Sociedade Anônima, 2 ed., Belo Horizonte: Del Rey, 2003, p.506.

${ }^{75}$ SANTANA, Maria Helena. O Novo Mercado e a Governança Corporativa. Revista CVM, p. 7 e 8. 2001.
} 
124 companhias se listaram nos níveis mais especiais de governança da Bolsa.

Para aderir ao Novo Mercado e aos Níveis 1 e 2, a companhia, seus controladores, administradores e a BM\&FBovespa, consoante a Resolução CMN n 2.690, de 28.01.2000, assinam um contrato em que, assumem a obrigação de cumprir o regulamento específico. A Bovespa assume também a tarefa de fiscalizar e garantir o enforcement das normas estabelecidas no regulamento ${ }^{77}$.

\subsection{Nível 1 de Governança Corporativa}

As companhias que migram para tal segmento se comprometem a implementar melhores práticas no que tange à prestação de informações ao mercado e a dispersão acionária, se comprometendo com obrigações como por exemplo:

i. Devem apresentar um free float - ações em circulação no mercado, que represente o mínimo de $25 \%$ (vinte e cinco por cento) do seu capital social;

ii. Proibição do exercício cumulativo dos cargos de Diretor Presidente e Presidente do Conselho de Administração;

iii. Possuir uma política de negociação com valores mobiliários de sua emissão por administradores controladores e outras pessoas relacionadas à companhia;

iv. Possuir um código de conduta;

v. Uma vez por ano pelo menos, realizar reunião pública com analistas e outros interessados a fim de divulgar informações sobre a sua situação econômico-financeira, perspectivas e projetos;

\footnotetext{
${ }^{76}$ Initial public offering, é o evento que marca a primeira venda de ações de uma empresa no mercado de ações.

${ }^{77}$ SANTANA, Maria Helena. O Novo Mercado e a Governança Corporativa. Revista CVM, p. 5. 2001.
} 
vi. Além das informações já exigidas pela CVM, oferecer informações adicionais ao mercado, que devem ser prestadas nas informações Trimestrais - ITR e no Formulário de Referência;

vii. Divulgar um calendário anual que contenha a data da reunião pública e a da divulgação das informações financeiras programadas para o exercício social.

\subsection{Nível 2 de Governança Corporativa}

Já as companhias listadas no Nível 2 de Governança, devem atender além das regras aplicáveis ao Nível 1, uma série de regras que visam atribuir aos acionistas minoritários direitos especiais, tais como:

i. As ofertas públicas por alienação de controle devem ser realizadas com o oferecimento do mesmo preço pago ao acionista controlador a todos os acionistas minoritários, inclusive os titulares de ações preferenciais sem direito a voto ou com voto restrito;

ii. Direito de voto aos acionistas preferencialistas em relação a determinadas matérias de especial relevância, como a transformação, fusão, cisão da companhia; aprovação de contratos entre a companhia e seu acionista controlador, diretamente ou por meio de terceiros, assim como de outras sociedades em que o acionista controlador tenha interesse, sempre que, por força de disposição legal ou estatutária, sejam deliberados em Assembleia Geral; avaliação de bens destinados à integralização de aumento de capital da companhia; escolha de empresa especializada para determinação do valor econômico da companhia nos casos em que tal avaliação for requerida; e alteração ou revogação de dispositivos estatutários que alterem ou modifiquem 
quaisquer das exigências previstas para o Nível 2 de Governança Corporativa;

iii. Deve ser estabelecido nos seus estatutos sociais, que os conflitos surgidos entre os participantes do mercado de capitais em geral devem ser solucionados por meio da Câmara de Arbitragem do Mercado, constituída pela Bovespa;

iv. Obrigatoriedade de nas hipóteses de fechamento do capital ou cancelamento para registro em tal segmento, a companhia ou o acionista controlador realizar oferta pública de aquisição de todas as ações em circulação, no mínimo pelo valor econômico, calculado através de um laudo de avaliação elaborado por instituição ou empresa especializada, com experiência comprovada e independência em relação ao poder de decisão da companhia;

v. Previsão de que o Conselho de Administração será composto por no mínimo, 5 (cinco) membros com mandato unificado de até 2 (dois) anos, permitida a reeleição, e terá a participação de pelo menos, $20 \%$ (vinte por cento) de conselheiros independente em relação ao acionista controlador e à administração ordinária da companhia.

\subsection{O Novo Mercado}

O Novo Mercado obedece aos mesmos princípios dos Níveis Diferenciados 1 e 2, no entanto, possui uma diferença fundamental: enquanto as empresas dos Níveis 1 e 2 tem ações preferenciais negociadas na BM\&FBovespa, as companhias do Novo Mercado podem emitir tão somente ações ordinárias.

O Novo Mercado repousa sobre três bases principais. A primeira base é a informação completa destinada aos acionistas, cuja previsão no 
Regulamento do Novo Mercado (Seção VI - "Informações periódicas e eventuais que devem ser prestadas") supera aquela constante da lei societária. Com relação à segunda, diz respeito ao reforço das garantias patrimoniais dos minoritários no momento de sua saída da sociedade. E a terceira, por sua vez, consiste nas proteções estruturais que reforçam o princípio cooperativo ao enfraquecer o poder do controlador e apresentamse de duas formas: a previsão da existência apenas de ações ordinárias, o que dificulta que a sociedade seja conduzia apenas pelo sócio majoritário; e a previsão de resolução de todos os conflitos oriundos do Novo Mercado por arbitragem ${ }^{78}$, diante da especialidade das cortes arbitrais, as quais tem condições e competência suficiente para analisar o mérito de decisões assembleares, a fim de eliminar, senão evitar, os conflitos societários. ${ }^{79}$

\subsection{A reforma do regulamento do Novo Mercado}

Em 2010, BM\&FBovespa promoveu uma audiência restrita que teve como missão alterar os regulamentos dos níveis diferenciados de Governança Corporativa. Os debates sobre as alterações tiveram início em 2009, quando foi realizado pela BM\&FBovespa vários fóruns com as companhias, com o intuito de discutir novas regras para a constante evolução no Novo Mercado. O resultado de tal audiência foi publicado pela BM\&FBovespa em 09.09.2010. O quadro a seguir mostra, dentre as principais discussões, as aprovadas e rejeitadas pelas companhias ${ }^{80}$ :

\begin{tabular}{|c|c|}
\hline APROVADAS & REJEITADAS \\
\hline $\begin{array}{l}\text { Divulgação obrigatória dos } \\
\text { cargos que os administradores } \\
\text { ocupam em outras entidades. }\end{array}$ & $\begin{array}{l}\text { Conselhos de administração } \\
\text { compostos de, pelo menos, } 30 \% \text { de } \\
\text { independentes. }\end{array}$ \\
\hline
\end{tabular}

\footnotetext{
${ }^{78}$ Previsão no art. 13.1, Seção XIII do Regulamento do Novo Mercado.

79 ALMEIDA, Caroline. Governança Corporativa: Arbitragem, administração de conflitos societários e desenvolvimento econômico e social. Dissertação (Programa de Pós Graduação em Direito) do Centro de Ciências Jurídicas e Sociais da Pontifícia Universidade Católica do Paraná, Curitiba, 2007, p.160.

${ }^{80}$ LISKAUSKAS, Suzana. Bola para frente. Revista Capital Aberto - 10 anos de Novo Mercado. n.33.São Paulo, abril 2012. 26-28p.
} 


\begin{tabular}{|l|l|}
\hline $\begin{array}{l}\text { Elaboração e divulgação } \\
\text { obrigatória de uma política de } \\
\text { negociação. }\end{array}$ & $\begin{array}{c}\text { Obrigatoriedade do comitê } \\
\text { de auditoria. }\end{array}$ \\
\hline $\begin{array}{l}\text { Veto à limitação de voto em } \\
\text { percentual inferior a 5\%. }\end{array}$ & $\begin{array}{c}\text { OPA obrigatória diante de } \\
\text { aquisições de 30\%. }\end{array}$ \\
\hline $\begin{array}{l}\text { Veto à aquisição de OPA } \\
\text { diante da aquisição de fatia pré- } \\
\text { determinada de capital. }\end{array}$ & \\
\hline $\begin{array}{l}\text { Manifestação obrigatória } \\
\text { dos Conselhos de Administração } \\
\text { diante de OPAs. }\end{array}$ \\
\hline \multicolumn{2}{|c|}{ Veto ao acúmulo dos cargos } \\
de CEO e chairman. \\
\hline
\end{tabular}

É indiscutível que o principal desafio do Novo Mercado é a constante evolução das regras de governança deste segmento. No entanto, em 2010, a reforma do regulamento do Novo Mercado demonstrou que a BM\&FBovespa pode encontrar sérios obstáculos para elevar as práticas de governança do seu mais rebuscado nível de listagem.

Não obstante disposições relevantes tenham sido aprovadas, como a proibição ao acúmulo de cargos de $C E O$ e chairman $^{81}$ e a manifestação obrigatória do Conselho de Administração diante de ofertas públicas de aquisição de ações, outros tão ou mais importantes foram barrados. Dentre esses pode-se citar as propostas de aumento de $20 \%$ (vinte por cento) para $30 \%$ (trinta por cento) da proporção mínima de membros independentes nos Conselhos de Administração; a obrigatoriedade do Comitê de Auditoria; e a oferta pública de aquisição de ações para quem atingir 30\% (trinta por cento) do capital. ${ }^{82}$

\footnotetext{
${ }^{81}$ Também designado de Presidente do Conselho.

${ }^{82}$ LISKAUSKAS, Suzana. Bola para frente. Revista Capital Aberto - 10 anos de Novo Mercado, n.33. São Paulo. Abril 2012. p. 26 - 27.
} 
Apesar disso, a BM\&FBovespa continua com esses assuntos em pauta já pensando numa nova reforma para trazer melhorias ao Novo Mercado, conforme afirmado pelo diretor de relações com emissores da BM\&FBovespa, Carlos Alberto Rebello. ${ }^{83}$

Segundo Carlos Alberto Rebello, os mercados estão cada vez mais dinâmicos, e se outras jurisdições que não a nossa apresentarem melhores praticas de governança, certamente vão captar mais recursos, portanto, há a extrema necessidade de evolução.

Foi constatado que, embora tenha sido rejeitada a proposta de adoção compulsória do Comitê de Auditoria, muitas companhias adotaram o órgão em substituição a um Conselho Fiscal mais potencial. De acordo com o anuário de Governança Corporativa da revista Capital Aberto, entre 2009 e $2010^{84}$, o percentual de empresas que possuíam um Conselho fiscal com funções, também de Comitê de Auditoria, diminuiu de 28\% (vinte e oito por cento) para $15,6 \%$ (quinze vírgula seis por cento).

O Comitê de Auditoria visa a evitar que a companhia se exponha a riscos desnecessários, já o Conselho Fiscal tem a função de fiscalizar as ações da empresa, após elas serem realizadas, são funções completamente diferentes.

Muitos atribuem a rejeição à adoção obrigatória do Comitê de Auditoria a uma questão de custo, mas segundo Carlos Alberto Rebello ${ }^{85}$ deve-se ao desconhecimento do mercado em relação à função e as vantagens do órgão.

Em relação à recusa das companhias em adotar Conselho de Administração com pelo menos $30 \%$ (trinta por cento) de independentes, a Institutional Shareholder Services (ISS), consultoria de governança e voto de assembleias mais influentes do mundo, anunciou que vai recomendar aos

\footnotetext{
${ }^{83}$ REBELLO, Carlos Alberto. Entrevista concedida à revista Capital Aberto - 10 anos de Novo Mercado, n. 33, São Paulo. Abril 2012, p. 27.

${ }^{84}$ LACHINI, Luciana. Perdendo Potência. Revista Capital Aberto. Ano 4. Anuário de Governança Corporativa $2011 . \quad$ Disponível $\langle$ http://www.capitalaberto.com.br/ler_artigo.php?pag=3\&sec=80\&i=4256 $>$ Acesso em 20.09.2012.

${ }^{85}$ REBELLO, Carlos Alberto. Op.cit., p. 28.
} 
seus clientes que votem contra a eleição de chapas ou candidatos aos Conselhos de Administração de companhias do Novo Mercado que não distribuam no mínimo, 30\% (trinta por cento) das cadeiras para independentes ${ }^{86}$.

Segundo o código de melhores práticas do $\operatorname{IBGC}^{87}$ a quantidade ideal de independentes nas companhias depende no grau de maturidade da organização, do seu ciclo de vida e de suas características.

Vale mencionar que Conselheiro Independente caracteriza-se por ${ }^{88}$ :

i. Não ter qualquer vínculo com a companhia, exceto participação de capital;

ii. Não ser acionista controlador, cônjuge ou parente ate segundo grau daquele, ou não ser ou não ter sido, nos últimos três anos, vinculado à sociedade ou entidade relacionada ao acionista controlador;

iii. Não ter sido, nos últimos três anos, empregado ou diretor da companhia, do acionista controlador, ou de sociedade controlada pela companhia;

iv. Não ser fornecedor ou comprador, direto ou indireto, de serviços e/ou produtos da companhia;

v. Não ser cônjuge ou parente ate segundo grau de algum administrador da companhia;

vi. Não receber outra remuneração da companhia além de conselheiro.

Além disso, serão considerados independentes também os conselheiros que tenham sido eleitos mediante faculdade prevista no art. 141, parágrafos $4^{\circ}$ e $5^{\circ}$ ou pelo art. 239 caput da Lei $6.404 / 76^{89}$.

Segundo Vasconcellos ${ }^{90}$, para manter-se independente e desempenhar bem o seu papel, o conselheiro deve: (i) ter preocupação com

\footnotetext{
${ }^{86}$ LISKAUSKAS, Suzana. Bola para frente. Revista Capital Aberto - 10 anos de Novo Mercado. n.33. São Paulo, Abril 2012, p.27.

Código de Melhores práticas do IBGC. Disponível em: $\langle$ http://www.ibgc.org.br/CodigoMelhoresPraticas.aspx $>$ Acessado em 20.09.2012.

${ }^{88}$ Regulamento de Listagem do Novo Mercado. Disponível em: < http://www.bmfbovespa.com.br/Pdf/RegulamentoNMercado.pdf $>$. Acesso em 20.09.2012.

${ }^{89}$ Lei 6.404/76, Art. 239. "As companhias de economia mista terão obrigatoriamente Conselho de Administração, assegurado à minoria o direito de eleger um dos conselheiros, se maior número não lhes couber pelo processo de voto múltiplo."
} 
a sua reputação; (ii) ser comprometido com a companhia, não devendo participar de diversos conselhos; (iii) manter a distância certa de acionistas e executivos para que conheça a fundo a companhia para poder contribuir com críticas e sugestões, mas não esteja muito perto de forma a comprometer a sua independência; (iv) estar preparado para sair a qualquer momento, não devendo criar laços afetivos com a companhia, uma vez que a sua posição não é eterna; e (v) ter seus interesses alinhados com os da companhia.

$\mathrm{O}$ custo que as companhias teriam para aumentar o percentual de independentes foi considerado como um dos principais motivos da resistência das companhias em adotar $30 \%$ (trinta por cento) pelo menos, de independentes. No entanto, pesquisa realizada pelo IBGC e publicada em março, constatou que conselhos que detêm $20 \%$ (vinte por cento) de independentes e companhias com mais de $30 \%$ (trinta por cento) desses profissionais gastam em média um valor bem semelhante para remunerar os membros deste órgão, sendo o valor anual respectivamente de $\mathrm{R} \$ 240,6$ mil (duzentos e quarenta vírgula seis mil) e $\mathrm{R} \$ 232,2$ mil (duzentos e trinte e dois vírgula dois mil) ${ }^{91}$.

Outra relevante rejeição das companhias foi a proposta de o acionista que atingir $30 \%$ (trinta por cento) do capital da companhia ser obrigado a fazer uma oferta pública de aquisição de ações a todos os acionistas. Quanto mais reduzido esse percentual, menores as chances de um investidor ou um grupo de investidores assumirem uma fatia relevante do capital e opinarem sobre os rumos da administração.

Da mesma forma, não agradou os investidores o mecanismo de fixação do preço da oferta com base no maior valor de mercado dos últimos 12 (doze) meses, acabando com a possibilidade de emissão pelo valor econômico.

\footnotetext{
${ }^{90}$ VASCONCELLOS, Paulo Conte. A importância dos conselheiros independentes. Revista RI: relações com investidores, Rio de Janeiro: n. 77, jul. 2004. p. 20-2.

${ }^{91}$ LISKAUSKAS, Suzana. Bola para frente. Revista Capital Aberto - 10 anos de Novo Mercado. n. 33. São Paulo, Abril 2012, p.28
} 
Trata-se na verdade de uma complexa tarefa estabelecer uma única regra de oferta publica de aquisição de ações, tendo em vista que as companhias têm estruturas de controle diferentes, sendo assim, o que para uma empresa de capital pulverizado pode ser bom, para outra, com estrutura holding pode ser ruim.

\subsection{A aproximação do Nível 2 ao Novo Mercado.}

A reforma promovida em 2010 pela BM\&FBovespa aproximou o Novo Mercado ao Nível 2 de Governança ao aumentar os requerimentos exigidos para o Nível 2. Desta forma, alguns críticos começaram a se perguntar se não teria desta forma o Nível 2 se tornado um concorrente do Novo Mercado?

Para alguns críticos as regras de governança do Novo Mercado não são mais tão diferenciadas assim, principalmente se houver uma comparação com as do Nível 2, visto que a única diferença entre os dois é a espécie de ações em circulação.

No Nível 2 as empresas são autorizadas a negociar ações preferenciais e ordinárias, enquanto no Novo Mercado podem apenas possuir papéis ordinários, que oferecem direito a voto. O ponto comum entre ambas é que as empresas que se listaram no Nível 2, a partir de maio de 2011 (a partir da entrada em vigor das regras) também passaram a ter que cumprir a regra de concessão de tag along ${ }^{92}$ de $100 \%$ para todos os acionistas.

No entanto, as empresas listadas no Nível 2 oferecem direito de voto aos minoritários em decisões relevantes e ainda permitem ao emissor alavancar o capital de sua companhia sem renunciar o controle acionário, por isso começou-se a questionar se o Nível 2 não teria se tornado um concorrente do Novo Mercado.

\footnotetext{
${ }^{92}$ A previsão do tag along está no art. 254-A, da Lei 6.404/76, é consiste no fato de o acionista que não faz parte do bloco de controle tem direito a vender suas ações por valor igual ou superior a $80 \%$ (oitenta por cento) daquele pago por ação com direito a voto, quando da alienação de controle pela companhia.
} 
Uma decisão que poderia ter mantido a sofisticação diferenciada do Novo Mercado seria ter aprovado a proposta de oferta pública de ações obrigatória para quem atingir 30\% (trinta por cento) do capital, visto que os outros direitos que foram adicionados ao Novo Mercado, como por exemplo, a separação dos cargos de $C E O$ e chairman e a manifestação sobre qualquer oferta pública de aquisição de ações da companhia também passaram a valer para o Nível $2 .^{93}$

Atualmente participar do Novo Mercado não é mais garantia de alta procura pelas ações, pois após os mais recentes escândalos que companhias do Novo Mercado apresentaram em suas estruturas de governança, os investidores já aprenderam que no Novo Mercado há companhias que são realmente confiáveis e sérias em suas políticas e outras que somente ostentam possuírem políticas rigorosas de governança, quando a realidade é bem diferente.

Pode-se citar como um desses problemas envolvendo má governança o ocorrido no processo de incorporação da construtora Tenda pela Gafisa, que se encontravam listadas no Novo Mercado, no qual houve muito questionamento por parte dos investidores visto que a troca de controle não proporcionou aos acionistas minoritários da Tenda o tag along.

Isso demonstra que muitas empresas listadas no Novo Mercado não estão focadas no cumprimento das regras, ao passo que pode-se afirmar também que há companhias no Nível 2 com uma governança mais eficiente quando comparadas ao Novo Mercado.

Não se pode negar o fato que a diferença entre os dois níveis de governança é grande, visto que o direito a uma ação com voto possui um grande valor nas melhores práticas de governança, no entanto, fazer parte do Novo Mercado não é condição suficiente para muitos investidores comprarem ações ${ }^{94}$, muitos investidores podem optar por investir em uma

\footnotetext{
${ }^{93}$ DEL CARO, Luciana. Posto Ameaçado. Revista Capital Aberto, n. 33. São Paulo. Abril 2012, p.31.

${ }_{94}^{94}$ PIRES, Fernando. Entrevista concedida para: DEL CARO, Luciana. Posto Ameaçado. Revista Capital Aberto, n. 33. São Paulo. Abril 2012, p. 31.
} 
empresa com duas classes de ações, desde que ela demonstre ter um bom potencial de crescimento e acertadas práticas de gestão.

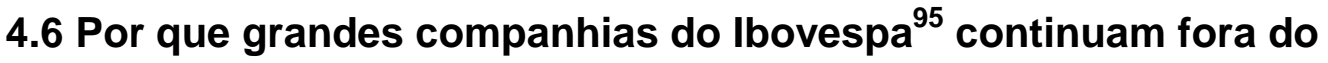 Novo Mercado}

Segundo entrevista concedida por Edemir Pinto, presidente da BM\&FBovespa ${ }^{96}$ há uma expectativa de que daqui a cinco anos, o Novo Mercado e o Bovespa Mais (destinados a IPOs de empresas de pequeno porte), serão os únicos a existir. No entanto, para isso acontecer será preciso ainda que muitas companhias migrem para o segmento mais sofisticado de governança corporativa.

Em 31 de janeiro de 2012, estavam listadas no Ibovespa 65 (sessenta e cinco) empresas, das quais 29 (vinte e nove) não faziam parte do Novo Mercado. No entanto, essas 29 empresas juntas somam uma capitalização de mercado de $\mathrm{R} \$ 1,5$ trilhão (um vírgula cinco trilhão), enquanto que as empresas listadas no Novo Mercado capitalizam juntas R\$500 milhões (quinhentos milhões). ${ }^{97}$

O que faz surgir uma questão: por que boas partes das companhias do Ibovespa continuam fora do Novo Mercado?

A maior parte das empresas do Ibovespa que não estão listadas no Novo Mercado, estão listadas no Nível 1 de governança. Um dos motivos que justificam essas companhias não adotarem as mais rebuscadas práticas de governança seria a obrigatoriedade de adoção da Câmara de Arbitragem do Mercado (CAM), que foi criada em 2001, pela BM\&FBovespa para ser um foro de resolução de conflitos societários. Muitas companhias tem preferência por adotar outras câmaras de arbitragem, com justificativas de serem mais aceitas internacionalmente.

\footnotetext{
95 Índice composto de ações emitidas por empresas que correspondem a mais de $80 \%$ do número de negócios e do volume financeiro da Bolsa.

${ }^{96}$ PINTO, Edemir. Revista Capital Aberto, n.33,São Paulo. Abril 2012, p.32 - 33.

97 ROCKMANN, Roberto. Faltam as gigantes. Revista Capital Aberto, n. 33. São Paulo.Abril 2012, p. 35.
} 
Um outro motivo seriam os problemas relacionados a regulação. Por exemplo, um fato regulatório que impede grandes companhias como é o caso da Gol e da Tam, migrarem para o Novo Mercado, é o fato de que empresas do setor de aviação comercial não podem ter mais de $20 \%$ (vinte por cento) do capital votante em poder dos estrangeiros, conforme consta no Código Brasileiro de Aeronáutica:

Art. 181. A concessão somente será dada à pessoa jurídica brasileira que tiver:

II - pelo menos 4/5 (quatro quintos) do capital com direito a voto, pertencente a brasileiros, prevalecendo essa limitação nos eventuais aumentos do capital social;

Uma reforma do Código Brasileiro de Aeronáutica (CBA) que ampliava esse limite para 49\% (quarenta e novo por cento) chegou a ser aprovada em comissão especial da Câmara dos Deputados, em 2010, e está pronta para apreciação em plenário.

Outra grande companhia que não pode aderir ao Novo Mercado por questões regulatórias é a Petrobrás, visto que segundo a Lei do Petróleo, o capital da empresa deve ser dividido entre ações preferenciais e ordinárias, e a União deve possuir a maior parte dos papéis com voto.

Há por outro lado, grandes companhias como é o caso da Ambev,Vale, Souza Cruz, Pão de Açúcar e Lojas Americanas que não possuem impedimentos regulatórios, mas todavia não ingressam no Novo Mercado.

Ocorre que o Novo Mercado tem o papel de tornar a companhia aos olhos dos investidores como uma companhia comprometida a seguir boas práticas de governança. No entanto, mesmo que a empresa não esteja listada no segmento do Novo Mercado, mas seja uma empresa que já tem um histórico de transparência e bom relacionamento com os acionistas, ela não precisa deste selo do Novo Mercado para atrair investidores.

Estar listado no Novo Mercado é sempre bom para essas companhias, no entanto, não é fundamental dado todo o histórico e 
solidificação que elas já possuem no mercado. Entretanto, para as novas companhias é indispensável.

Outra questão que dificulta as grandes companhias a migrarem para o Novo Mercado é o fato de que muitas companhias estão estruturadas há muito tempo com ações preferenciais e ordinárias, não tornando tão simples a migração para o Novo Mercado, acredita-se que com o tempo essas empresas vão se adequar e migrar para o Novo Mercado.

Há inclusive, precedentes da CVM no sentido de autorizar a redução do quorum qualificado na deliberação sobre conversão de ações preferenciais em ordinárias, quando for o caso de haver elevada dispersão das ações preferenciais no mercado de modo que não se consiga obter o quórum de deliberação exigido no art. 136, caput, da Lei 6.404/76, quando da realização da Assembleia Especial. Visando desta forma facilitar a migração para o Novo Mercado. Nesse sentido ${ }^{98}$ :

PEDIDO DE AUTORIZAÇÃO PARA REDUÇÃO DE QUORUM QUALIFICADO NA DELIBERAÇÃO SOBRE CONVERSÃO DE AÇÕES PARANAPANEMA.S.A.-PROC.RJ2009/10433. Reg.nº6741/09,Relator: DOZ

"A Companhia relata, em seu pedido, que, como parte de um processo de reestruturação, a sua administração fixou como objetivo o seu ingresso no Novo Mercado da BM\&F Bovespa. Para tanto, em atendimento ao disposto no inciso II do art. 136 da LSA, a administração procurou submeter à Assembleia Especial a aprovação da conversão das ações preferenciais em ordinárias. No entanto, em virtude da elevada dispersão das ações preferenciais no mercado, as três últimas tentativas de realizar a Assembleia Especial fracassaram, não se tendo alcançado, em nenhuma dessas oportunidades, o quórum de deliberação exigido no caput do art. 136 da LSA.

Em sua manifestação, consubstanciada no RA/CVM/SEP/GEA-4/nº117/09, a Superintendência de Relações com Empresas - SEP posicionou-se favoravelmente à retirada do quorum qualificado para a referida deliberação, tendo em vista inclusive os precedentes já julgados pelo Colegiado, ressaltando que a administração da Companhia deve continuar a adotar medidas para incentivar a participação dos acionistas preferencialistas na Assembleia Especial.

Por fim, o Relator reforçou a recomendação feita pela área técnica, no sentido de que, em qualquer hipótese, a Companhia deve continuar a adotar medidas para incentivar a participação dos acionistas preferencialistas no processo de deliberação de conversão das ações de sua titularidade.

O Colegiado deliberou o deferimento do requerimento da Paranapanema S.A., nos termos do voto apresentado pelo Relator Otavio Yazbek."

\footnotetext{
98 Ata de Reunião do Colegiado da CVM,número 48, de 15.12.2009. Disponível em: <http://www.cvm.gov.br/port/descol/resp.asp?File=2009-048d15122009.htm>. Acessado em 30.10.2012.
} 
De todo modo, ter uma boa governança vale tanto quanto ter uma boa gestão ${ }^{99}$, para os investidores não há impeditivo em comprar ações de companhias fora do Novo Mercado, no entanto, estar listada no nível mais sofisticado de governança é sempre um fator importante a ser considerado pelas empresas.

${ }^{99}$ TRALLI, Frederico. Entrevista concedida para: ROCKMANN, Roberto. Faltam as gigantes. Revista Capital Aberto, n. 33. São Paulo. Abril 2012. p. 36. 


\section{Capítulo 5: As perspectivas para o Novo Mercado}

Ainda que a governança corporativa no Brasil tenha dado um grande salto em sua evolução nos últimos anos, o país ainda precisa melhorar muito para estar no primeiro time de governança mundial.

Passadas mais de uma década desde a criação do Novo Mercado é preciso que as autoridades atualizem suas regras sempre atentas ao futuro e ao desenvolvimento dos outros mercados ${ }^{100}$. Pois se compararmos as práticas do Novo Mercado com as práticas de governança de alguns mercados mais avançados, conclui-se que a governança no Brasil ainda está atrasada.

É inegável que as boas condições da economia brasileira contribuíram muito para o sucesso do Novo Mercado, no entanto, hoje resta um novo desafio. É fundamental que as regras do Novo Mercado sejam aprimoradas para que não se tornem obsoletas ${ }^{101}$.

A reprovação de propostas relevantes na reforma em 2010 demonstrou que deve ser revisto o fato de a condução das alterações do segmento ficar a cargo das companhias. O Novo Mercado nasceu de uma iniciativa da Bolsa e das empresas, e é justamente por isso que as reformas no segmento são conduzidas em parceria com elas. No entanto, a partir do momento em que este fato começa a impedir que ocorram avanços necessários, tal posicionamento deve ser revisto.

Em nenhuma outra bolsa no mundo há a necessidade do voto positivo de dois terços dos emissores para aprovar alterações nas regras de listagem. Obviamente as empresas devem ser ouvidas, mas não deve caber a elas o poder definitivo de decisão ${ }^{102}$.

\footnotetext{
${ }^{100}$ MUTO, Silvio. É preciso evoluir. Revista Capital Aberto,n. 33. São Paulo, Abril 2012 ,p. 46. ${ }^{101}$ WONG, Simon. Entrevista concedida para: MUTO, Silvio. É preciso evoluir. Revista Capital Aberto, n. 33. São Paulo, Abril 2012, p. 47.

${ }^{102}$ Ibid.
} 
Outro ponto que merece atenção para a evolução do Novo Mercado é a criação de um código de fusões e aquisições, para haver regras mais claras e eficientes na hipótese de ocorrer um tag along.

Em 2010, a BM\&FBovespa encomendou ao advogado Nelson Eizirik a produção de um código que solucionasse a questão, a primeira versão já foi entregue, mas ainda não há prazo para entrada em vigor.103

O mercado está ficando mais seletivo, o mercado está ficando mais atento ao Brasil, novos investidores olham para o Brasil, e esses investidores são mais técnicos e querem mais precisão que discurso.

No seminário "Emissores, Investidores e Autorreguladores: Perspectivas para o Novo Mercado", no dia 12/07/2012, realizado pela BM\&FBovespa, Maria Helena Santana ${ }^{104}$, ex presidente da CVM, falou sobre o trabalho que vem sendo feito para atrair empresas de menor porte ao mercado de capitais. Segundo ela, há um esforço de diagnóstico sendo feito por um grupo de atores público e privado, a Bolsa, a CVM, o Fundo de Investimentos em Estudos e Pesquisas (FINEP), a Associação Brasileira de Direitos a Informática (ABDI), estão discutindo, estudando, procurando entender outras experiências para em um futuro ser aplicado aqui. Maria Helena Diniz discorreu que os mercados que conseguiram viabilizar o acesso de empresas menores são muito diversificados entre si, adotam modelos muito diferentes entre si e as regras são muito mais fortes que as brasileiras. Ela afirmou que um ponto no qual deve haver atenção seria para que houvesse descontos regulatórios para as empresas menores, deve-se estudar o que é possível fazer para melhorar a relação custo beneficio para essas empresas.

No mesmo evento Marcelo Trindade, advogado na área de mercado de capitais discorreu que ele considera como um desafio é a formação das pessoas, dos profissionais que vão trabalhar nas companhias abertas para

\footnotetext{
${ }^{103}$ CARVAlHO, Antonio. "Falta um código de fusões e Aquisições". Revista Capital Aberto.Disponível em: http://www.capitalaberto.com.br/ler_artigo.php?pag=3\&sec=47\&i=4670>. Acesso em 12.09.2012. ${ }^{104}$ Disponível em: TV BM\&FBovespa: $<$ http://www.tvbmfbovespa.com.br/Videos/1512 $>$ Acesso em 14.09.12.
} 
assegurar que as companhias que já estão ou vão se listar no Novo Mercado mantenham um nível de qualidade de informação financeira e não financeira adequado, de modo que tenhamos investidores que corram apenas os riscos que eles devem correr,que são os riscos do sucesso ou não sucesso do negócio, mas não os riscos por estarem mal informados.

Pode-se adicionar também a questão dos conselheiros independentes, Alexandre di Miceli ${ }^{105}$ ressalta que o tempo de mandato também deve ser levado em consideração na avaliação de independência do conselheiro, visto que com o passar dos anos a liberdade pode ficar prejudicada. Um conselheiro independente de longa data pode tornar-se amigo do $C E O$ e de toda a diretoria, o que atrapalha a independência de seu trabalho.

Observa Di Miceli ainda, a qualificação dos conselheiros que muitas vezes só estão na empresa porque determinado acionista o colocou, e não porque tem a devida qualificação para desempenhar a função.

No campo da autorregulamentação há o debate sobre a implementação do "comply or explain" ("pratique ou explique"). Adotado em países desenvolvidos como Reino Unido, França e Alemanha, e também em países como Argentina, Colômbia, Peru, México e Panamá, o sistema prevê uma série de regulamentações sobre governança, cujo cumprimento é facultativo. As companhias devem apenas divulgar publicamente quais praticas não estão sendo seguidas e explicar o porquê dessa opção. ${ }^{106}$

Segundo os autores Simone Azevedo e Silvio Muto, essa ideia não é nova no Brasil. Em 2002, quando a CVM lançou sua cartilha de governança corporativa, ela tentou colocar em prática essa ideia, quando colocou na cartilha que exigiria uma "breve" inclusão nas informações anuais das companhias abertas, de indicação sobre o nível de adesão às

\footnotetext{
${ }^{105}$ MICHELLI, Alexandre. Visão internacional. Revista Capital aberto, ano 5, edição especial: "10 anos de governança corporativa no Brasil". São Paulo. Abril 2008. 46 - 49 p.

${ }^{106}$ AZEVEDO, Simone; MUTO, Silvio. Longo Caminho. Revista Capital Aberto. Disponível em: 〈http://www.capitalaberto.com.br/ler_artigo.php?pag=3\&sec=28\&i=2109>. Acesso em 14.09.2012.
} 
práticas recomendadas na cartilha. No entanto, as empresas protestaram muito e a CVM resolveu então não colocar em prática o modelo.

As críticas a essa ideia vão no sentido de que constrangeria a companhia ter que expor publicamente as razões de suas escolhas, bem como de que demandaria tempo e dedicação dos executivos, aumentando a burocracia das companhias.

No entanto, a adoção deste modelo poderia tornar o mercado brasileiro mais transparente. Hoje as empresas podem simplesmente ignorar as recomendações de governança, e o investidor, não tem noção sobre este quadro, a não ser que ele se disponha a estudar vários documentos sobre as companhias $^{107}$.

Um outro ponto de perspectiva se refere ao custo, de acordo com o presidente da bolsa paulista, Edemir Pinto ${ }^{108}$, o custo para manter uma empresa aberta no Brasil é muito alto, principalmente por causa das divulgações obrigatórias no Diário Oficial. Tendo em vista que muitas empresas reclamam da dificuldade que tem em implementar muitas práticas de governança em razão do custo que essas empresas teriam, parece razoável pensar em medidas que minimizem os custos e a burocracia para as companhias. Por este motivo, a bolsa paulista está conversando com a Associação Brasileira das Companhias Abertas (Abrasca) para propor uma alternativa à regra atual. Segundo ele, a ideia é fazer uma proposta que seja reconhecida pela CVM e pelo governo, para que as companhias abertas com faturamento anual de até $\mathrm{R} \$ 500$ milhões (quinhentos milhões de reais) utilizem o meio online para a publicação de resultados e outros comunicados. Já havia sido feito uma proposta nesse sentido para o governo anterior, que, no entanto, foi vetada.

\footnotetext{
107 MICELI, Alexandre. Longo Caminho. Revista Capital Aberto. Disponível em: < http://www.capitalaberto.com.br/ler_artigo.php?pag=3\&sec=28\&i=2109>. Acesso em 14.09 .2012 ${ }_{108}$ BRONZATI, ALINE. Disponível em: Revista "Isto é Dinheiro", 12 de maio de 2012, Disponível <http://www.istoedinheiro.com.br/noticias/83906_BMFBOVESPA+QUER+AMPLIAR+EXIGEN

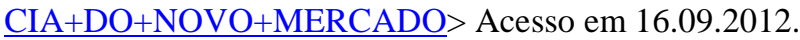


Há também a polemica da saída do Novo Mercado. Conforme divulgado na imprensa ${ }^{109}$ o Itaú vem tentando fechar o capital da processadora de cartões Redecard, da qual é controlador. A regra prevê que o Itaú faça uma oferta aos minoritários, que dizem se aceitam ou não o preço proposto.

No entanto, o Itaú prometeu tirar a Redecard do Novo Mercado caso os acionistas não aceitassem a sua oferta. Os acionistas ficaram muito preocupados, visto que a saída do Novo Mercado seria muito prejudicial aos seus interesses. Por fim, o Itaú acabou recuando a ameaça, mas este fato gerou muita preocupação dentre os investidores.

A perspectiva de que as empresas possam simplesmente sair do Novo Mercado pela simples vontade do controlador causa preocupação aos investidores. Desta forma, deveriam ser discutidas regras mais claras para a saída do segmento.

\subsection{A proposta do Takeover Panel}

Com o objetivo de disciplinar as transferências de controle acionário no Brasil, o advogado Nelson Eizirik, a pedido da BM\&FBovespa, elaborou em seu escritório, juntamente com algumas das principais associações do mercado de capitais, as bases de um novo modelo que se encontra em análise. A proposta consiste na criação de um Comitê de Fusões e Aquisições (CAF), uma associação privada, que será confiada a uma comissão de nove membros, dos quais cinco serão indicados pelas entidades do mercado e quatro independentes, além do auxílio de um quadro técnico profissional.

\footnotetext{
109 BRONZATTO, Thiago. "Mercado Novo com cheiro de velho na Bovespa?". Revista Exame, edição 1015, em 03 de maio de 2012. Disponível: <http://exame.abril.com.br/revistaexame/edicoes/1015/noticias/mercado-novo-com-cheiro-de-velho-na-bovespa?page=1>. Acessado em 14.09.2012.
} 
Segundo o advogado Nelson Eizirik ${ }^{110}$, o estudo consistiu na análise do chamado "dualismo regulatório", que é uma tendência em países cujas elites empresariais resistem a mudanças. A ideia é criar um marco regulatório que coexista com o antigo, de forma a estabelecer um novo e mais rigoroso regime de proteção aos minoritários, que irá atuar paralelamente ao existente, e cuja adesão será voluntária. Além disso, irá atuar sempre em colaboração com a CVM.

O objetivo de se implementar um órgão inspirado no Takeover Panel, é dar mais um passo na evolução das melhores práticas de governança corporativa, de forma a conferir maior segurança aos acionistas e aprimorar o sistema de governança no Brasil.

A função do Comitê de fusões e aquisições é aplicar o Código de Autorregulação de aquisições e fusões, que vai disciplinar todas as modalidades de ofertas públicas de fusões e aquisições, bem como as operações de reestruturação societária. O código irá muito além da legislação e regulamentação da CVM, no que diz respeito às exigências de comutatividade das operações e de proteção aos investidores.

Pode-se citar dentre os principais princípios que compõem do Código de Autorregulação de aquisições e fusões: obrigatoriedade de OPA quando o ofertante atingir $30 \%$ (trinta por cento) do capital votante da empresa-alvo; tratamento igualitário para os titulares da mesma classe de ações, ampla divulgação das informações; necessidade dos acionistas sempre serem ouvidos e restrição ao ingresso de companhias que apresentem dispositivos estatutários evidentemente ilegais como as chamadas "cláusulas pétreas".

De acordo com Eizirik, o modelo dará certo porque estarão sujeitas às decisões do CAF apenas as companhias abertas que quiserem, de forma que a adesão poderá ser permanente, com a atribuição de "selo de qualidade

110 EIRIZIK, Nelson. Revista Capital Aberto, edição 96. Disponível em: $<$ http://www.bmfbovespa.com.br/juridico/noticias-e-entrevistas/Noticias/O-Takeover-Panel-e-omodelo-ideal-para-disciplinar-transferencias-de-controle-acionario-no-Brasil.asp>. Acessado em 14.09.2012. 
CAF", ou somente em determinada operação. E as companhias aceitariam participar disso pelo mesmo motivo que entraram no Novo Mercado, visto que tratar bem os minoritários valoriza as ações da companhia e permite captar recursos no mercado de capitais mais facilmente.

\subsection{As Poison Pills e a defesa das companhias de takeover hostis.}

As cláusulas de defesa contra aquisições hostis, ou, poison pills, foi objeto de intensa discussão quando se tentou padronizá-las no grupo de empresas listadas no Novo Mercado.

A cláusula obriga que um acionista que atinge determinado percentual de participação a fazer uma oferta pública para adquirir a totalidade das ações. O objetivo é que a oferta obrigatória desanime eventuais interessados em alcançar posições relevantes na empresa comprando os papéis na Bolsa, sem negociar com os acionistas principais.111 Considera-se que esta proteção visa conferir maior estabilidade à administração, e também assegura que mudanças no controle de gestão não ocorram da noite para o dia.

Em 2010, a BM\&FBovespa fez um levantamento sobre a incidência de poison pills entre as companhias listadas no segmentos mais sofisticados de governança, das 106 (cento e seis) empresas analisadas, 65 (sessenta e cinco) possuíam controlador definido, e dentre elas 49,23\% (quarenta e nove vírgula vinte e três) tinham esse mecanismo de proteção. ${ }^{112}$

A padronização dessas cláusulas, como queria a BM\&FBovespa na reforma do Novo Mercado, foi rejeitada e ignorada pelas empresas listadas no segmento à época. A intenção da Bolsa era que todas as companhias do Novo Mercado tivessem a mesma regra: uma cláusula que obrigasse o investidor que reunisse 30\% (trinta por cento) do capital a realizar uma

\footnotetext{
${ }_{111}^{111}$ YOKOI, Yuki. Golpe Batido. Revista Capital Aberto. Ano 8, n. 90. São Paulo, fev.2011, p. 15. ${ }^{112}$ Ibid.
} 
oferta pública de aquisição de ações por um preço equivalente ao maior valor pago pelo acionista adquirente nos 12 (doze) meses anteriores ${ }^{113}$.

As empresas que adotaram essa proteção geralmente estabelecem um percentual com gatilho inferior a 30\% (trinta por cento) e cada empresa estabelece um percentual diferente de gatilho.

Segundo Andrade e Rossetti ${ }^{114}$, uma das mais importantes inovações da nova lei 6.404/76 foi a que estabeleceu a obrigatoriedade de assegurar preço mínimo igual a $80 \%$ (oitenta por cento) aos acionistas minoritários, em relação ao preço pago aos integrantes do bloco de controle. Trata-se do tag along, ou direito de saída conjunta, que consiste no alongamento do prêmio pago pelo controle da companhia, assegurando maior proteção patrimonial aos minoritários.

Para os autores, o impacto dessa mudança não é pequeno, sendo, por um lado, uma proteção às minorias fora dos blocos de controle que confere tratamento mais paritário, mediante oferta pública simultânea para a aquisição de suas ações ao preço mínimo agora definido em lei, mas, de outro lado, não deixa de ser uma espécie de poison pill imposta pela lei, que aumenta os custos das operações de take-over, desestimulando-as ou, mais profundamente ainda, desincentivando aberturas e promovendo fechamentos de capital.

Contudo, essa inovação tem alcance limitado, pois não abrange as ações preferenciais, apenas as ordinárias nas mãos dos minoritários não controladores, sendo que as preferenciais somente são alcançadas pelo tag along em situações peculiares como a que a lei lhes confere na hipótese de não-pagamento compensatório de dividendos por três exercícios consecutivos. ${ }^{115}$

\footnotetext{
${ }^{113}$ YOKOI, Yuki. Golpe Batido. Revista Capital Aberto. Ano 8, n. 90. São Paulo, fev.2011, p. 15. 114 ANDRADE, Adriana; ROSSETTI, José Paschoal. Governança corporativa: fundamentos, desenvolvimento e tendências. 2. ed. São Paulo: Atlas, 2006. 108 p.

${ }^{115}$ MAGALHÃES, Letícia. Governança Corporativa: Sua evolução e a iniciativa brasileira do Novo Mercado da Bolsa de Valores. Nova Lima, 2007. 78 p.Dissertação( Mestrado) da Faculdade de Direito Milton Campos.
} 
Segundo Yuki Yokoi ${ }^{116}$, as companhias até reiteram o interesse em manter cláusulas antitakeover em seus estatutos, mas não mostram qualquer movimento no sentido de diversificá-las.

As poison pills apareceram no Brasil estimuladas pela recente desconcentração de capital decorrente das ofertas públicas. Desde então, não houve preocupação em criar uma poison pill diversificada das adotadas por algumas empresas brasileiras.

Já houve tentativas de aumentar a proteção dessas cláusulas, no entanto, sem sucesso.

Uma exceção foram as empresas que chegaram a criar uma proteção a mais para essas cláusulas, chamadas de "cláusulas pétreas", que obrigam o acionista que viesse a votar a favor da exclusão do dispositivo, a obrigação de fazer ele mesmo a oferta de aquisição, de forma a evitar qualquer tentativa eliminar o empecilho.

Pode-se também citar as "cláusulas de restrição de voto", adotadas por empresas como a Embraer, que tem como objetivo limitar os direitos políticos de acionistas que obtenham participações notáveis, fixando o seu poder de voto em determinado porcentual. Por exemplo: se esse acionista atingir 30\% (trinta por cento) de participação, seus votos contarão apenas com 5\% (cinco por cento) de participação. A intenção é preservar a pulverização do capital, para que ele não volte a ser concentrado ${ }^{117}$.

Há, segundo Yuki Yokoi, um motivo para o Brasil ter poucos tipos de poison pills: mesmo que atualmente a base acionária das companhias seja mais dispersa do que há dez anos, ocorre ainda um acúmulo de participações em poder de poucos acionistas. Isso faz com que o Brasil precise menos de instrumentos antitakeover.

O mercado norte-americano, pelo contrário, possui uma grande diversidade de mecanismos de defesa. Podemos citar como exemplo a poison pill do tipo flip-in, que prevê que diante de aquisição de participação

\footnotetext{
${ }^{116}$ YOKOI, Yuki. Golpe Batido. Revista Capital Aberto. Ano 8, n. 90. São Paulo, Fev.2011, p. 15.

${ }^{117}$ Ibid. p.16.
} 
relevante, seja feito um aumento de capital dirigido a todos os acionistas, menos ao adquirente. Assim, haveria uma diluição do potencial comprador $^{118}$.

Há também a pílula denomina flip-over que confere à empresa alvo o direito de comprar a preços descontados as ações da companhia que tenta aquisição hostil. Seria inserta uma cláusula no estatuto da companhia alvo, que se aplicaria sobre a companhia compradora ${ }^{119}$.

Além disso, nos Estados Unidos as poison pills podem ser instituídas pelos conselhos de administração sem a necessidade de estarem nos estatutos sociais e sem precisar de assembleia. Já no Brasil, se exige que a inclusão ou alteração de uma poison pill no estatuto seja feita em assembleia de acionistas.

A legislação societária brasileira também não estimula a invenção de novas fórmulas : a Lei das S.As é mais rigorosa em questões que visam proteger os acionistas minoritários, como por exemplo preservando expressamente o direito de preferência e impede diluições injustificadas de participação.

Segundo o IBGC ${ }^{120,}$ essas cláusulas devem ser encaradas com certa reserva. Devem ser menos recomendadas principalmente nas companhias que possuem controlador definido, ou então aquelas que possuem um capital em circulação no mercado que não seja suficiente para garantir a alguém o controle acionário.

Durante o período em que houve uma grande quantidade de ofertas públicas iniciais, as poison pills foram incluídas nos estatutos sociais dessas companhias sem o menor cuidado. Das 103 (cento e três) companhias que abriram o capital nesse período (de 2004 a 2008), 65 (sessenta e cinco) continham essa cláusula.

\footnotetext{
${ }^{118}$ YOKOI, Yuki. Golpe Batido. Revista Capital Aberto. Ano 8, n. 90. São Paulo, Fev.2011, p.18. ${ }^{119}$ Ibid.

${ }^{120}$ MUTO, Silvio. Vida Nova, código novo. Revista Capital Aberto, Ano 6, n.71. São Paulo, julho 2009 , p. $31-32$.
} 
No entanto, veio a grande crise internacional de 2008 e as cotações caíram; com isso, houve muitas oportunidades de realizações de fusões e aquisições que não puderam ocorrer devido a essas cláusulas. Desta forma, a estratégia de preservar a companhia contra aquisições hostis se virou contra os acionistas controladores, que perderam boas oportunidades de venda de participação para um sócio estratégico.

\subsection{0 modelo do Comply or Explain}

Durante o processo de revisão das regras do Novo Mercado, houve a sugestão da implementação de uma espécie de modelo do "comply or explain", de forma a permitir que uma série de novas práticas fossem adicionadas aos requerimentos de listagem do Novo Mercado ${ }^{121}$.

Segundo a secretária geral do IBGC, Heloísa Bedicks, as empresas não teriam a obrigação de cumprir essas práticas; no entanto, precisariam explicar quando não aderissem a elas.

Contudo, essa ideia não prosperou no Brasil. Por outro lado, o IBGC, em seu código, inseriu um tipo de "ensaio" para o "comply or explain" em algumas de suas recomendações.

No que se refere à remuneração dos executivos, o IBGC recomenda a divulgação individual dos ganhos dos gestores ou, no mínimo, a divulgação dos salários agregados do Conselho de Administração e da Diretoria. Caso não seja realizada a divulgação de forma individual, a companhia deve justificar sua opção de forma completa, ampla e transparente ${ }^{122}$.

Esse sistema tem sido alvo de discussão no mundo inteiro. O modelo foi criado no Reino Unido, em 1992, no primeiro código de

\footnotetext{
${ }^{121}$ BEDICKS, Heloísa. Opção para gente grande. Revista Capital Aberto. Ano 6, n.71. São Paulo, julho $2009.36 \mathrm{p}$.

${ }_{122}$ GUERRA, Sandra. Opção para gente grande. Revista Capital Aberto, Ano 6, número 71. São Paulo, julho 2009. 6 p.
} 
governança do país, o Cadbury Report ${ }^{123}$, e o objetivo, é exigir mais da companhias sem obrigá-las. A única obrigação é que caso não pratiquem certa determinação, exponham publicamente suas razões ${ }^{124}$.

O ponto de discussão desse sistema está no "explique". O ideal seria que quando uma companhia não seguisse certa recomendação, os investidores julgassem se a justificativa para o não cumprimento é coerente, e houvesse uma reflexão sobre essa avaliação na cotação dos papéis.

Desta forma, seria necessário que houvesse analistas cientes da importância desta regra, além de capacitados para analisar as justificativas das empresas.

No entanto, para que este modelo desse certo seria essencial que houvesse investidores ativos, que cobrassem das empresas o cumprimento das recomendações e explicações coerentes para a não conformidade. Fato que claramente está longe de ser o que ocorre no Brasil, onde os investidores não estão interessados, nem tem condições de fazer esse tipo de monitoramento.

Segundo o autor ${ }^{125}$, há também um problema na qualidade e na confiabilidade das justificativas que as companhias apresentam.

Na Alemanha, o "comply or explain" é usado desde 2002, e sofre problemas no que tange ao "explain", visto que as companhias se utilizam de respostas vagas como por exemplo: "a prática é conflitante com as políticas internas da empresa" ou "a prática é contraprodutiva".

Assim como no Brasil, a Alemanha tem uma grande concentração de empresas com controlador definido e pouco ativismo por parte dos minoritários, de forma que há pouquíssimo questionamento das informações prestadas, pouco interesse, e falta de engajamento por parte dos investidores. Como consequência, as informações prestadas são muito

\footnotetext{
${ }^{123}$ O Relatório Cadbury é defendido por alguns como o verdadeiro marco da governança corporativa no mundo: esse documento tornou-se inspiração para iniciativas em muitos países, tendo em vista que foi desenvolvido no primeiro estágio do movimento pela governança corporativa.

${ }^{124}$ MUTO, Silvio. Opção para gente grande. Revista Capital Aberto, Ano 6, número 71. São Paulo. Julho 2009. 35 p.

${ }^{125}$ Ibid. p. 35
} 
generalizadas, de difícil verificação, tendo o país baixa adesão às práticas que são sugeridas e baixa qualidade nas informações fornecidas. ${ }^{126}$

Não é a toa que o percentual de empresas na Alemanha que se submetem a todas as indicações do Cromme Code (código da Alemanha) é inferior a 20\% (vinte por cento). Já no Reino Unido, a adesão é superior a $50 \%$ (cinquenta por cento) das companhias.

No Brasil, o "comply or explain" poderia trazer aos investidores maior conhecimento sobre as práticas de governança, de forma a levar a discussão dos temas de forma mais séria dentro das companhias.

Há muita resistência por parte das empresas que argumentam que este modelo aumentaria a burocracia e constrangeria as companhias brasileiras, que não tem o costume de publicar detalhes de seu funcionamento.

Nessa perspectiva, parece-nos que ainda vai demorar, para que este modelo um dia possa ser implementado com sucesso no Brasil. Será necessário um movimento coordenado para sua adoção no país, um amadurecimento das companhias sobre as práticas de justificar as informações com clareza e qualidade. Falta essa cultura ao brasileiro. Além da conscientização do investidor que deve se encarregar de fazer pressão sobre as companhias para que se adequem às práticas de forma confiável e forneçam as informações de maneira completa.

Sem que haja a cultura de fiscalização dos próprios investidores sobre as informações fornecidas pelas companhias, dificilmente este modelo funcionará adequadamente no país.

\subsection{A divulgação da remuneração dos administradores}

Um dos pontos de maior polêmica trazido pela Instrução Normativa 480 da CVM foi a remuneração dos administradores.

\footnotetext{
${ }^{126}$ GUERRA, Sandra. Opção para gente grande. Revista Capital Aberto, Ano 6, número 71. São Paulo. Julho 2009. 36 p.
} 
A partir de 2010, depois de muita reclamação a CVM tornou obrigatória divulgação das remunerações mínima, média e máxima dos salários dos diretores e conselheiros de administração, além da composição dos salários entre parcelas fixa e variável.

No entanto, foi realizada uma análise cuidadosa dos resultados obtidos no segundo ano de vigência da norma ${ }^{127}$, que demonstrou que os resultados ainda deixam a desejar, sendo ainda uma fonte distorcida, na qual as empresas divulgam os resultados de formas discrepantes.

As informações sobre remuneração permitem fazer uma série de considerações sobre as práticas de governança de uma companhia, por isso tão importantes os dados exigidos pela CVM. Afinal, a empresa é pública e trabalha com capital de terceiros, desta forma, deve satisfação.

Já há efeitos da maior transparência trazida pela Instrução Normativa 480 da CVM. Reportagem do jornal Valor Econômico ${ }^{128}$, mostrou que pela primeira vez após a instrução 480 houve a rejeição em assembleia de proposta de remuneração de uma empresa listada na Bolsa, incentivada por acionistas estrangeiros que reclamaram da falta de detalhes no pacote de remuneração da alta administração.

No entanto, nem todas as companhias aceitaram exibi-los. Segundo pesquisa realizada pela revista Capital Aberto $^{129}$, das 99 empresas analisadas no anuário, 14,4\% (quatorze vírgula quatro por cento) não divulgaram a proporção entre parcela fixa e variável, 26\% (vinte e seis por cento) não apresentaram as informações sobre as mínimas, médias e máximas remunerações dos executivos, e $24 \%$ (vinte e quatro por cento) não revelaram quanto pagam aos seus conselheiros de administração. Essas empresas se apoiam em uma liminar obtida pela na justiça pelo Instituto Brasileiro dos Executivos de Finanças do Rio de Janeiro (Ibef-RJ) para não

\footnotetext{
${ }^{127}$ MAIA, Bruno. Revista capital aberto, ano 9, número 100, São Paulo, dezembro/2011. 46 p. ${ }^{128}$ CARVALHO, Denise e TORRES, Fernando. Arrocho salarial, jornal Valor Econômico em 04/05/2011. Disponível em:< http://www.valor.com.br/arquivo/885631/arrocho-salarial $>$. Acessado em 19.09.2012.

${ }^{129}$ MAIA, Bruno. Revista capital aberto, ano 9, número 100. São Paulo, dezembro/2011. 50 p.
} 
divulgarem esses valores, sob a alegação de que esse tipo de informação colocaria em risco a segurança de seus profissionais.

O Instituto Brasileiro de Governança Corporativa (IBGC) apresentou130 pesquisa que revela o patamar de remuneração praticado pelas empresas de capital aberto no Brasil para conselheiros de administração, diretores estatutários e conselheiros fiscais. O levantamento, que traz dados consolidados de 2010 das 189 companhias listadas na BM\&FBovespa, apresentou dentre outros os seguintes resultados:

Em 2012, 18,65\% (dezoito vírgula sessenta e cinco por cento) das empresas fizeram uso da liminar do Ibef-Rj, contra $24 \%$ (vinte e quatro por cento) em 2011.

Apesar disso, ainda há muita resistência quanto à divulgação desses valores, o que prejudica a transparência com acionistas e demais stakeholders. Segundo a pesquisa, os dados sugerem que as companhias que se valeram da liminar apresentam salários maiores em todos os órgãos com relação à média das outras companhias.

A pesquisa revelou que as empresas de controle familiar apresentaram a maior média salarial para conselheiros de administração, seguida por organizações de capital pulverizado e compartilhado. As controladas pelo estado, no entanto, apresentaram o menor nível de remuneração, por terem teto legal definido.

Concluiu-se que o Novo Mercado continua sendo o segmento com maior consistência em termos de remuneração: menor número de empresas que utiliza a liminar e menor variabilidade nos dados.

Em relação ao conselho de administração foi observado que houve um aumento dos salários acima dos índices de inflação do período.

Um fato bastante polêmico é que alguns executivos passam a ganhar cinco, até dez vezes mais, sem que, no entanto, a companhia tenha lucrado o dobro, ou tenha sequer dobrado de tamanho. Há uma aparente $\begin{array}{llll}130 & \text { Remuneração dos administradores 2012, IBGC. } & \text { Disponível } & \text { em: }< \\ \text { http://www.ibgc.org.br/Pesquisas.aspx }>\text { Acessado em 21.09.2012. } & \end{array}$ 
desconexão entre o aumento da remuneração dos executivos e a criação de valor para os acionistas.

Matéria publicada no jornal Estadão ${ }^{131}$ demonstra esse fato. Segundo a matéria o banco HSBC teve uma queda de cerca de $\mathrm{R} \$ 2$ bilhões (dois bilhões) do seu lucro, mas o presidente da financeira ganhou 16 milhões (dezesseis milhões) em bônus pelo seu trabalho.

A informação só aumentou o debate sobre a desproporção entre os ganhos dos executivos e o desempenho de suas companhias. Este debate começou com a crise de 2008 nos Estados Unidos, quando os profissionais do setor foram alvo de protestos, por receberem altas quantias de dinheiro, quando as empresas que trabalhavam apresentavam péssimos resultados.

Segundo o autor da matéria, Silvio Guedes"132: "Parece óbvio afirmar que os profissionais devem receber de acordo com o que eles contribuem para a empresa. O que não é evidente é como calcular essa contribuição. Os resultados trimestrais, por si só, não são suficientes para dizer se o trabalho dos profissionais foi bom ou ruim".

Será que disparidades como essa continuariam ocorrendo se os investidores saíssem de sua zona de conforto, ficassem mais conscientes e começassem a votar a verba global nas assembleias gerais ordinárias e começassem a discutir seriamente os pacotes de remuneração dos executivos? Certamente, falta essa cultura no Brasil, e para que se vislumbre uma remuneração justa dos administradores, essa discussão e conscientização por parte investidores dos seus direitos como sócios é um caminho essencial a se trilhar.

\footnotetext{
${ }^{131}$ CRESPO, Sílvio Guedes. "Presidente do HSBC leva bônus de R\$ 16 milhões após queda no lucro”. Estado de São Paulo.São Paulo, fevereiro/2012. Disponível em: $<$ http://blogs.estadao.com.br/radar-economico/2012/02/27/com-queda-no-lucro-chefe-do-hsbcganha-bonus-de-r-16-mi/ > . Acessado em 16.09.12.

${ }_{132}$ Ibid.
} 


\section{Considerações finais}

Conforme todo o exposto, nos últimos 10 (dez) anos tivemos uma enorme evolução em termos de Governança, e o Brasil sem dúvida é um dos países que está tirando significativo proveito das boas práticas de Governança, mas o tema ainda possui diversas lacunas para melhorias, tendo em vista que somente uma minoria das organizações vinculadas ao mercado de capitais está realmente em estágio de eficácia dessas práticas.

O país como um todo está em fase de aprimoramento, mas é preciso atenção ao fato de que muitas empresas ainda adotam em seus relatórios e websites discursos e publicidade em torno das boas práticas de Governança, quando na verdade estão bem distantes da prática efetiva do dia a dia, ou a exercem de maneira superficial.

Há uma relevante preocupação em torno da capacidade dos gestores, membros do conselho de administração, CEOs e executivos em geral não estarem suficientemente preparados para antecipar fatores de risco e vulnerabilidade das empresas. É necessário que haja uma dedicação efetiva e profunda dos tomadores de decisão no que diz respeito à identificação e prevenção de riscos que afetam as empresas, mas que não são recorrentes. Há de haver uma aproximação entre a área de gestão de risco com o Conselho de Administração para que haja uma eficiência na detecção de fatos extraordinários com antecedência.

A Governança Corporativa está intimamente ligada a aspectos de eficiência com o objetivo de que haja um conjunto de informações capaz de fornecer mais previsibilidade sobre determinados fatos, prevenindo a ocorrência de surpresas.

Um dos deveres inerentes aos administardores, para os critérios da Governança, é o dever fiduciário. O administrador de recursos deve satisfação e respeito a terceiros que confiam seus recursos a ele. Os administradores das companhias abertas possuem o dever de informar (art. 
157 da LSA). No entanto, tem sido observada uma forte falta de compromisso das empresas em relação a este item.

Conforme demonstrado ao longo deste trabalho, as companhias, quando do preenchimento do Formulário de Referência (que é o principal instrumento de comunicação para prestação de contas da companhia), não vem fornecendo as informações necessárias à compreensão e avaliação da companhia pelos investidores de forma adequada. Verifica-se um sério problema de transparência por parte das empresas ao fornecer as informações exigidas pelo formulário.

Meu entendimento é no sentido de que deveria haver maior fiscalização por parte da CVM, até mesmo melhor detalhando-se o que deve ser obrigatoriamente divulgado. A adequada publicação das informações pelas companhias proporcionaria uma melhor compreensão acerca dos valores mobiliários por ela emitidos, além de que possibilitaria aos pesquisadores o desenvolvimento de experiências com outras variáveis importantes, tornando o estudo sobre a governança no Brasil mais desenvolvido, e desta forma contribuindo para um mercado de capitais mais próspero.

Por outro lado há de haver um grande amadurecimento em relação ao aspecto cultural. Prevalece uma falta de hábito dos investidores pessoa física em ter uma atuação mais ativa, fiscalizadora e de participação nas decisões das empresas. Tendo em vista que a participação desses investidores é limitada, eles deveriam comparecer às assembleias, fazerem cobrança aos executivos sobre os rumos perseguidos pela empresa, deveria haver uma questionamento sobre as políticas adotadas, a forma de remuneração, a escolha dos conselheiros, entre outras.

É de extrema importância para o mercado de capitais que o investidor se conscientize de que ele precisa comparecer às assembleias, precisa ter uma postura proativa e questionadora, e que cobre dos órgãos reguladores (CVM e Poder judiciário) o respeito aos seus direitos. 
Há um problema no mercado de capitais brasileiro no que diz respeito à falta de demanda a esses órgãos reguladores. Para que esses órgãos tenham o funcionamento esperado e eficaz, é necessário que ele seja efetivamente demandado. As pessoas precisam ir a esses órgãos e reclamarem a proteção de seus direitos.

No Brasil, essa situação é um pouco mais difícil, sob dois aspectos: o primeiro e mais grave, já mencionado, é a questão do absenteísmo enraizado na cultura no investidor brasileiro. A mudança na postura do acionista em desenvolver um engajamento na vida da sociedade, é fundamental para o desenvolvimento do mercado de capitais. O outro aspecto se refere aos custos. Essas pessoas teriam que contratar advogados especializados, o que os desestimula a buscarem seus direitos.

Como consequência desses fatos, esses órgãos reguladores acabam sendo menos demandados, o que diminui a qualidade da discussão e precisão técnica sobre o assunto, resultando em menos precedentes, tornando esses assuntos menos desenvolvidos e dificultando o entendimento por parte das pessoas de como as sociedades anônimas devem funcionar.

Pode-se mencionar também como uma preocupação para desenvolver o mercado de capitais no Brasil, o fato de que devem-se estudar meios para atrair as empresas de menor porte ao mercado de capitais. Conforme já mencionado anteriormente, uma forma de viabilizar o acesso a essas empresas e que deve ser avaliado, seria a possibilidade de haver descontos regulatórios para empresas menores, de forma a melhorar a relação custo/ beneficio para essas empresas.

Para que haja um aprimoramento na qualidade no mercado de capitais, é importante que o governo conceda incentivos fiscais de modo que haja uma desconcentração das empresas que abrem o seu capital.

Um dos pontos de maior reflexão nos últimos anos se refere aos avanços nas discussões sobre o desempenho do conselho de administração, que hoje tem liderança nas decisões estratégicas. 
Conforme mencionado, os conselhos de administração devem balizar o poder dos gestores para que estes não tomem decisões desalinhadas com o interesse da companhia e dos acionistas. Os conselhos de administração são importantes para desafiar a gerência executiva.

Em conclusão, o foco hoje está nas discussões sobre a adoção de avaliação para conselheiros e conselho, a organização de seu funcionamento, a qualificação de sua composição, a diversidade em termos de gênero e perfil dos conselheiros.

No meu entendimento, um ponto que merece devida atenção, e é alvo de muitas críticas, como já antes mencionado, é o baixo nível de engajamento de muitos conselheiros, que não participam das discussões e estão completamente alheios e desinteressados sobre o funcionamento da companhia. Observou-se também que muitos conselheiros não dedicam a devida atenção a um cargo com tamanha responsabilidade, muitos sequer buscam ter conhecimento das responsabilidades sob as quais está submetido.

É importante, que o conselheiro tenha consciência de que ele está ali para representar os interesses da empresa, e não do acionista que o elegeu, como aludido anteriormente.

Conselheiros que atuam como figurantes podem trazer consequências desastrosas para o patrimônio dos acionistas no longo prazo.

Fato comum que se observa, e que não tem obtido melhora nos últimos anos segundo as pesquisas apresentadas, é a informalidade e desorganização presente nos conselhos. Isto também já foi mencionado antes. Verificam-se conselhos sem regimentos, as reuniões não são marcadas com antecedência, nem possuem materiais de qualidade, muitas vezes não há nem registro em ata das reuniões. Desta forma, é inviável que um conselho funcione bem.

Por conseguinte, parece-me que estamos em uma fase de transição. Segundo as pesquisas apresentadas ${ }^{133}$, já houve um enorme aprimoramento

\footnotetext{
${ }^{133}$ Dados da evolução da governança no Brasil, p. 32, desta monografia.
} 
no que diz respeito à evolução dos conselhos de 2001 para cá. Mas obviamente ainda temos muito a desenvolver para estarmos no primeiro time de governança mundial.

O grande avanço da Governança Corporativa no Brasil foi sem dúvida, a criação do Novo Mercado e dos Níveis diferenciados de governança da Bovespa. No entanto, ao comemorarmos neste ano, os dez anos de implementação e funcionamento do Novo Mercado, surge uma maior reflexão sobre o novo desafio deste segmento, que é manter suas regras atualizadas para que não se tornem obsoletas, e é aí que está a maior dificuldade enfrentada pelo segmento.

Há de haver a consciência de que o mercado externo está ficando mais atento ao Brasil, e esses investidores estrangeiros são mais seletivos, mais técnicos e querem mais precisão.

Conforme mencionado ao longo deste trabalho, em 2010 houve a reforma do regulamento do Novo Mercado, no qual acendeu-se um alerta vermelho para as dificuldades que a imprescindível atualização das regras deste segmento pode vir a enfrentar.

Apesar de ter havido importantes aprovações (proibição do acúmulo dos cargos de $C E O$ e chairman e manifestação obrigatória do Conselho de administração diante de OPAs), foram barradas importantíssimas disposições que elevariam o Novo Mercado a um nível mais elevado de segurança e desenvolvimento, como é o caso do aumento de $20 \%$ (vinte por cento) para $30 \%$ (trinta por cento) da proporção mínima de membros independentes nos Conselhos de Administração.

Se esta disposição tivesse sido aprovada, representaria uma enorme contribuição para o desenvolvimento e funcionamento do conselho, que é o órgão com mais peso na estrutura de governança. Os conselheiros independentes tem grande importância dentro de um conselho, pois tendem a ser mais imparciais nas decisões que envolvem os acionistas controladores. 
Isso porque, como leciona Steinberg, ${ }^{134}$ há três classes diferentes de conselheiros: os conselheiros internos, que são diretores ou empregados da corporação; os conselheiros externos, que não trabalham na companhia, mas não são independentes; e os conselheiros independentes, que não têm vínculo com a corporação, não trabalham para ela, nem oferecem produto ou serviço, não são cônjuges ou parentes, não recebem outra remuneração da organização, mas trabalham para o bem dela e de todos os acionistas.

Outra rejeição importante foi à adoção obrigatória de comitês de auditoria. A função do comitê de auditoria é evitar que o a companhia se exponha a riscos desnecessários, e conforme demonstrado anteriormente ${ }^{135}$, há uma séria falta de credibilidade do quesito prevenção de riscos. Aparentemente há ainda um desconhecimento do mercado em relação às vantagens do órgão.

Há de serem buscados meios para tornar o mercado de capitais brasileiro mais transparente, por isso é importante que se prossiga na discussão de mecanismos que possam contribuir com este objetivo, por exemplo, como já mencionado, a implementação do modelo do "comply or explain", que traria aos investidores maior conhecimento acerca das práticas de governança adotadas pelas companhias, e poderia ampliar a discussão e seriedade dos temas pelas companhias.

É preciso a consciência de que o Novo Mercado é o ponto de partida, e não de chegada. É imprescindível que a BM\&FBovespa continue discutindo esses assuntos e traga novas melhorias para o Novo Mercado, visto que os mercados estão cada vez mais dinâmicos e exigentes, e se quisermos continuar captando recursos, não podemos descuidar da extrema necessidade de aprimoramento das regras.

\footnotetext{
${ }^{134}$ STEINBERG, H. A dimensão humana da governança corporativa: pessoas criam as melhores e piores práticas. São Paulo: Editora Gente, 2003.247 p.

${ }_{135}$ Pesquisa PriceWaterCoopersHouse "iii. Os entrevistados manifestaram insatisfação com a eficácia dos Conselhos de Administração na prevenção e gestão de riscos, $51 \%$ (cinquenta e um por cento) deles estão insatisfeitos ou muito insatisfeitos", p. 35 desta monografia.
} 


\section{Referências Bibliográficas}

ALMEIDA, Caroline. Governança Corporativa: Arbitragem, administração de conflitos societários e desenvolvimento econômico e social. Dissertação(Programa de Pós Graduação em Direito) do Centro de Ciências Jurídicas e Sociais da Pontifícia Universidade Católica do Paraná, Curitiba, 2007.

ALMEIDA, Jennifer. RIs debatem as mudanças nas Instruções CVM 480 e 481. Revista RI. n. 141. São Paulo, p. 48. Março 2010.

ANDRADE, Adriana; ROSSETTI, José Paschoal. Governança Corporativa: Fundamentos, desenvolvimento e tendências. $2^{\mathrm{a}}$ ed. São Paulo: Atlas, 2006.

ANDRADE, Adriana; ROSSETTI, José Paschoal. Governança corporativa: fundamentos, desenvolvimento e tendências. 2. ed. São Paulo: Atlas, 2006.

Ata de Reunião do Colegiado da CVM,número 48, de 15.12.2009. Disponível em: <http://www.cvm.gov.br/port/descol/resp.asp?File=2009048d15122009.htm>. Acessado em 30.10.2012.

AZEVEDO, Simone. Um orgulho para o Brasil. Revista Capital Aberto Especial, n.33, São Paulo, abril 2012.

AZEVEDO, Simone; MUTO, Silvio. Longo Caminho. Revista Capital Aberto. Disponível em: <http://www.capitalaberto.com.br/ler_artigo.php?pag=3\&sec=28\&i=2109> . Acesso em 14.09.2012.

BEDICKS, Heloísa. Opção para gente grande. Revista Capital Aberto. Ano 6, n.71. São Paulo, julho 2009.

BEDICKS, Heloísa. Os motivos de governança: uma questão de saúde. Disponível em: < http://www.diagnosticoweb.com.br/especiais/os-motivosda-governanca-uma-questao-de-saude.html>. Acessado em 07.07.2010.

BRANDÃO, Mônica. Governança corporativa $e$ a influência dos acionistas minoritários no sistema de decisões estratégicas. Disponível em: $\quad\langle$ http://mrm.comunique-se.com.br/arq/132/arq_132_13827.pdf >. Acesso em 05.10.2012. 
BRONZATI, ALINE. Disponível em: Revista "Isto é Dinheiro", 12 de maio de 2012, Disponível em: $<$ http://www.istoedinheiro.com.br/noticias/83906_BMFBOVESPA+QUER + AMPLIAR+EXIGENCIA+DO+NOVO+MERCADO> Acesso em 16.09.2012.

BRONZATTO, Thiago. "Mercado Novo com cheiro de velho na Bovespa?". Revista Exame, edição 1015, em 03 de maio de 2012. Disponível: $\quad<$ http://exame.abril.com.br/revistaexame/edicoes/1015/noticias/mercado-novo-com-cheiro-de-velho-nabovespa?page=1 >. Acessado em 14.09.2012.

CADBURY, Adrian. The Cadbury Report - Relatório do Committee on the Financial Aspects of Corporate Governance, 1992.

CANTIDIANO, Leonardo. Novo Mercado: Dez anos de sucesso. Revista Capital Aberto. Disponível em : < http://www.capitalaberto.com.br/ler_artigo.php?pag=3\&sec=99\&i=4684> Acessado em 05.10.2012.

capitais brasileiro - o novo mercado. In: V SEMEAD, 2001, São Paulo.

CARVALHO, Antonio Gledson. Efeitos de Migração para os Niveis de Governança da Bovespa. Disponível em: < HTTP://www.bmfbovespa.com.br/pt-br/abmfbovespa/download/uspniveis.pdf >, acessado em 03.09.2012.

CARVALHO, Antonio. "Falta um código de fusões e Aquisições". Revista Capital Aberto.Disponível em: http://www.capitalaberto.com.br/ler_artigo.php?pag=3\&sec=47\&i=4670 $>$. Acesso em 12.09.2012.

CARVALHO, Denise e TORRES, Fernando. Arrocho salarial, jornal Valor Econômico em 04/05/2011. Disponível em:< http://www.valor.com.br/arquivo/885631/arrocho-salarial>. Acessado em 19.09.2012.

CLEMENTE, Eduardo Silveira. Governança Corporativa e questões jurídicas concretas. Disponível em: $<$ http://jus.com.br/revista/texto/6049/governanca-corporativa-e-questoesjuridicas-concretas/1>. Acessado em 05.10.2012.

Código de Melhores práticas do IBGC. Disponível em: $\langle$ http://www.ibgc.org.br/CodigoMelhoresPraticas.aspx $>$ Acessado em 20.09.2012.

CORRÊA LIMA, Osmar Brina. Sociedade Anônima, 2 ed., Belo Horizonte: Del Rey, 2003 
CRESPO, Sílvio Guedes. "Presidente do HSBC leva bônus de R\$ 16 milhões após queda no lucro". Estado de São Paulo.São Paulo, fevereiro/2012. Disponível em: <http://blogs.estadao.com.br/radareconomico/2012/02/27/com-queda-no-lucro-chefe-do-hsbc-ganha-bonusde-r-16-mi/ >. Acessado em 16.09.12.

CVM divulga Instrução que estabelece as regras de registro de emissores de valores mobiliários admitidos à negociação em mercados regulamentados. Disponível em: < http://www.cvm.gov.br/port/infos/Comunicado\%20\%207\%20de\%20dezembro.asp>. Acessado em 08.10.2012.

CVM divulga Instrução sobre informações e pedidos públicos de procuração para exercício do direito de voto. Disponível em: < http://www.cvm.gov.br/port/infos/Comunicado\%20\%2015\%20de\%20dezembro.asp>. Acessado em 10.10.2012.

CVM, publicação. Uma década de Governança Corporativa, 2006.

CVM.

em: $<$ http://www.cvm.gov.br/asp/cvmwww/atos/exiato.asp?File=\%5Cinst $\% 5 \mathrm{Ci}$ $\underline{\text { nst } 480 . h t m}>$. Acessado em 12.09.12.

DEL CARO, Luciana. Posto Ameaçado. Revista Capital Aberto, n. 33. São Paulo. Abril 2012

Disponível em: $\quad$ TV $\quad$ BM\&FBovespa:< http://www.tvbmfbovespa.com.br/Videos/1512 >Acesso em 14.09.12.

EIRIZIK, Nelson. Revista Capital Aberto, edição 96. Disponível em: $<$ http://www.bmfbovespa.com.br/juridico/noticias-e-entrevistas/Noticias/OTakeover-Panel-e-o-modelo-ideal-para-disciplinar-transferencias-decontrole-acionario-no-Brasil.asp>. Acessado em 14.09.2012.

EIZIRIK, Nelson; GAAL, Ariádna B.; PARENTE, Flávia; HENRIQUES, Marcus de Freitas. Mercado de Capitais - Regime Jurídico, edição 3. Rio de Janeiro: Editora Renovar. 2008.

FARIA, Andréa. Primeiras anotações sobre governança corporativa. Piracicaba, 2010. Dissertação (Mestrado). Departamento de direito da Universidade Metodista de Piracicaba.

FERREIRA, Patrícia; SILVA, Sabrina; SILVA, Antônio. Governança Corporativa e o Novo Mercado: uma estratégia de capitalização para o setor sucroalcooleiro. Disponível em: $<$ https://docs.google.com/viewer?url=http $\% 3 \mathrm{~A} \% 2 \mathrm{~F} \% 2 \mathrm{Fwww}$.ead.fea.usp.b r\%2Fsemead\%2F9semead\%2Fresultado_semead\%2FtrabalhosPDF\%2F326 .pdf>. Acessado em 06.10.2012. 
GALBRAITH, Jonh Kenneth. A economia das fraudes inocentes: verdades para o nosso tempo. Tradução de Paulo Anthero Soares Barbosa. São Paulo. 2004

GONZALEZ, Roberto. Sustentabilidade. Instruções 480 e 481: Um caminho para só relato e a voz do público estratégico.Revista RI. Rio de Janeiro: IMF Editora Ltda. Março 2010

GUERRA, Sandra. Opção para gente grande. Revista Capital Aberto, Ano 6, número 71. São Paulo, julho 2009.

Guia de orientação para melhores práticas de comitês de auditoria. Disponível em: http://www.ibgc.org.br/CadernoGovernanca.aspx?CodCaderno=53>.

Acessado em 06.10.2012.

Guia de orientação para o Conselho Fiscal. Disponível em: < http://www.ibgc.org.br/CadernoGovernanca.aspx?CodCaderno=2>. Acesso em 06.10.2012.

HILGERT, Paulo. Aprenda a Investir na Bolsa de Valores. 4 ed. XP Educação. p.17. Rio de Janeiro, jan. 2011.

IBGC e Booz\&co. Panorama da Governança Corporativa no Brasil. Disponível em:

http://www.google.com/url?sa=t\&rct=j\&q=\&esrc=s\&source=web\&cd=1\& ved=0CCAQFjAA\&url=http\%3A\%2F\%2Fwww.ibgc.org.br\%2FDownload. aspx\%3FRef\%3DPesquisaConhecimento\%26CodPesquisa\%3D20\&ei=ZfK FUMnCCYzU0gHC14DgCg\&usg=AFQjCNF0vekYOxJZfGzegwNa4k1FP g3pUw\&sig2=B_5DH7ic9_D4tiaTUlfYag >. Acesso em 25.09.2012.

IBGC. Disponível em: < http://www.ibgc.org.br/Historico.aspx $>$ Acesso em 06.10.2012.

LACHINI, Luciana. Perdendo Potência. Revista Capital Aberto. Ano 4. Anuário de Governança Corporativa 2011. Disponível em: $<$ http://www.capitalaberto.com.br/ler_artigo.php?pag=3\&sec=80\&i=4256 > Acesso em 20.09.2012.

LETHBRIDGE, E. Tendências da Empresa Familiar no Mundo. Revista $B N D E S \mathrm{n}^{\circ}$ 6. Rio de Janeiro, 1997.

LISKAUSKAS, Suzana. Bola para frente. Revista Capital Aberto - 10 anos de Novo Mercado. n. 33. São Paulo, Abril 2012.

MAGALHÃES, Letícia. Governança Corporativa: Sua evolução e a iniciativa brasileira do Novo Mercado da Bolsa de Valores. Nova Lima, 2007, Dissertação (Mestrado)Curso de direito da Faculdade de Milton Campos. 
MAIA, Bruno. Revista capital aberto, ano 9, número 100, São Paulo, dezembro/2011.

MICELI, Alexandre. A evolução dos Conselhos de Administração no Brasil e no mundo. Disponível em: $<$ http://www.google.com/url?sa=t\&rct=j\&q=\&esrc=s\&source=web\&cd=2 \&ved $=0 \mathrm{CCUQFjAB} \& u r l=\mathrm{http} \% 3 \mathrm{~A} \% 2 \mathrm{~F} \% 2 \mathrm{Fwww}$.ibgc.org.br\%2FDownloa d.aspx \%3FRef\%3DEventos\%26CodArquivo\%3D333\&ei=A_FUNuSEPSa 0gHM oHoDw\&usg=AFQjCNGqczRDMIdVU5aTCQ4N6kelL011Q\&sig2 $=$ hGSBOscIzIIrq2E_yoi9Rg>. Acessado em 12.09.2012.

MICELI, Alexandre. Governança Corporativa. Sustentare Escola de Negócios, Curso de Pós Graduação Lato sensu. Abril 2011. Disponível em:< http://www.slideshare.net/Sustentare/governana-corporativa-prof-dralexandre-di-miceli-da-silveira-sustentare-8415874 >. Acesso em 05.10.2012.

MICELI, Alexandre. Longo Caminho. Revista Capital Aberto. Disponível em: http://www.capitalaberto.com.br/ler artigo.php?pag=3\&sec=28\&i=2109>. Acesso em 14.09.2012

MICELI, Alexandre. Novos intérpretes, número 18, abril 2012. Disponível em: $<$ http://www.luzio.com.br/novosinterpretes. php?id=52394cf47127e93a6331d989c51955b7>. Acessado em 21.09.2012.

MICHELLI, Alexandre. Visão internacional. Revista Capital aberto, ano 5, edição especial: "10 anos de governança corporativa no Brasil". São Paulo. Abril 2008

Modelo de regimento interno de Conselho de Administração. Disponível em:

http://www.bmfbovespa.com.br/pdf/ModeloRegimentoInternoCA.pdf >. Acessado em 06.10.2012.

MUTO, Silvio. É preciso evoluir. Revista Capital Aberto,n. 33. São Paulo, Abril 2012.

MUTO, Silvio. Opção para gente grande. Revista Capital Aberto, Ano 6, n.71. São Paulo. Julho 2009.

MUTO, Silvio. Vida Nova, código novo. Revista Capital Aberto, Ano 6, n.71. São Paulo, julho 2009.

PINTO, Edemir. Revista Capital Aberto, n.33,São Paulo. Abril 2012.

PIRES, Fernando. Entrevista concedida para: DEL CARO, Luciana. Posto Ameaçado. Revista Capital Aberto, n. 33. São Paulo. Abril 2012. 
PRADO, José Domingos. Uma década de Novo Mercado. Revista Capital Aberto Especial, São Paulo, abril 2012.

PRICEWATERHOUSECOOPERS, Auditores Independentes. Governança Corporativa: um processo em evolução no Brasil, 2011. Disponível em: < http://www.pwc.com.br/pt BR/br/publicacoes/assets/gov-corporativa11.pdf $>$. Acesso em 26.10.2012.

QUATERLY, McKinsey. 3 reformas para a governança. Revista HSM Management, n. 47, Nov-dez 2004, São Paulo: Savana.

REBELLO, Carlos Alberto. Entrevista concedida à revista Capital Aberto 10 anos de Novo Mercado, n. 33, São Paulo. Abril 2012.

Regulamento de Listagem do Novo Mercado. Disponível em: < http://www.bmfbovespa.com.br/Pdf/RegulamentoNMercado.pdf $>$. Acesso em 20.09.2012.

Remuneração dos administradores 2012, IBGC. Disponível em:< http://www.ibgc.org.br/Pesquisas.aspx > Acessado em 21.09.2012.

RIBEIRO, Milton Nassau. Aspectos Jurídicos da Governança Corporativa. Belo Horizonte: Del Rey, 2007.

ROCKMANN, Roberto. Faltam as gigantes. Revista Capital Aberto, n. 33. São Paulo.Abril 2012.

SALOMÃO FILHO, Calixto. O novo direito societário, 2 ed., São Paulo: Malheiros, 2002.

SANTANA, Maria Helena. O Novo Mercado e a Governança Corporativa. Revista CVM, 2001.

STEINBERG, H. A dimensão humana da governança corporativa: pessoas criam as melhores e piores práticas. São Paulo: Editora Gente, 2003.

STEINBERG, Hebert. Apud Guilherme N. Dale, in A dimensão humana da governança corporativa, pessoas criam as melhores e as piores práticas. Editora Gente. 2003.

TRALLI, Frederico. Entrevista concedida para: ROCKMANN, Roberto. Faltam as gigantes. Revista Capital Aberto, n. 33. São Paulo. Abril 2012.

VASCONCELLOS, Paulo Conte. A importância dos conselheiros independentes. Revista RI: relações com investidores, Rio de Janeiro: n. 77, jul. 2004.

VIANA, Andréa. Governança Corporativa: Um panorama da evolução e das dificuldades das organizações brasileiras de agirem efetivamente em 
compliance às suas diretrizes. (LATEC/UFF) Disponível em: < https://docs.google.com/viewer?url=http $\% 3 \mathrm{~A} \% 2 \mathrm{~F} \% 2 \mathrm{Fwww}$.excelenciaemg estao.org\%2FPortals\%2F2\%2Fdocuments\%2Fcneg7\%2Fanais\%2FT11_03 72_2135.pdf >, Acessado em 07.10.2012.

VIEIRA, Solange Paiva; MENDES, André Gustavo Salcedo, "Governança Corporativa: Uma análise de sua evolução e Impactos no Mercado de Capitais Brasileiro", Revista BNDES, Rio de Janeiro, número 22, dez. 2004.

WONG, Simon. Entrevista concedida para: MUTO, Silvio. É preciso evoluir. Revista Capital Aberto, n. 33. São Paulo, Abril 2012.

YOKOI, Yuki. Golpe Batido. Revista Capital Aberto. Ano 8, n. 90. São Paulo, Fev.2011. 